\title{
Investigation on Alamparai Fort by Utilization of Organic Materials for Improvement of Stability of Heritage Structure
}

Kotteeswaran Santhanam ( $\nabla$ raviramadoss339@gmail.com )

SRM Institute of Science and Technology

Ravi Ramadoss

SRMIST: SRM Institute of Science and Technology

\section{Research Article}

Keywords: Alamparai fort, strength analysis, core-drilling, Diagonal shear, seismic analysis

Posted Date: June 21st, 2021

DOI: https://doi.org/10.21203/rs.3.rs-569773/v1

License: (c) (i) This work is licensed under a Creative Commons Attribution 4.0 International License. Read Full License 


\section{Abstract}

Heritage structures are valuable monuments to describe the culture and traditions of the country. These heritage structures get deformed in today's scenario by natural or artificial disasters. Hence, to preserve these heritage structures, restoration was introduced to restore the ancient building with new binding agents. Rehabilitation can take place only by analysing the properties of existing structures. Based on the existing structure properties, the alternative binding agent selected; can regain the same strength and shape of the heritage structures. Based on these, the restoration of Alamparai fort was performed by analysing the fort materials using mortar strength analysis by core-drilling, double punch test, and small-scale masonry test. The arch properties are also analysed by performing seismic analysis based on the mortar strength properties. The stability analysis of the organic and existing materials shows that Gur and haritaki is the best agent for restoring the fort. Hence, the mortar strength and seismic analysis of these materials performed using diagonal shear test and seismic modelling of the fort. The proposed material strength tests results indicate that the Gur and Haritaki is the best agent to restore the fort. The fort was restored with these materials; it survived in Nivar cyclone crossed on 26th November 2020.

\section{Introduction}

Most forts in India are castles or fortresses. However, when the Indian government classified India in the 17th and 19th centuries, they used the term fort that was common in Britain at the time. All fortresses, whether European or Indian, are called fortresses. Since then, this has become common in India. Three main methods were used to construct the Indian castle. The first is the earthen city wall. Usually, they are made of sand, which is dug from the ditches around the fortress. The second piece of rubble is outside, with dirt on it, making it stronger. The third type of building is stone and masonry buildings. The last one is the strongest. Usually, the materials in the demolished fortress are reused to build new fortresses. Although the sudden disaster did not destroy any Indian fortresses, several fortresses were abandoned due to the ambitions of the rulers and therefore deteriorated over time. Few castles have survived since the early Middle Ages and even the 14th to 15th centuries: most castles built in the 10th to 15th centuries have since been remodeled and remodeled. The castle was used as a residential area until the 19th-20th centuries, so it was constantly modified.

Built-in, the Mid-17th Century on the site of a seaport active since ancient times, Alamparai Fort (also known as "Alampara") has witnessed wars, earthquakes, tsunamis, and the ever-turning tides of imperial power. This old fort off a forgotten road along the Bay of Bengal is a favourite spot for photographers and off-the-beaten-track explorers of Tamil Nadu in south-eastern India. Alamparai Fort is an ancient structure located on the coast of the Bay of Bengal in the village of Alamparai. The location of the fort is about 106 kilometers south of ECR Chennai, Tamil Nadu, India. The latitude and longitude are respectively: $12.266^{\circ} \mathrm{N}$ and $80.010^{\circ} \mathrm{E}$. The fort was built in the Christian era under French rule in 1750 and during the Mughal period. There is a port by the sea, and there is a dock for commodities exchange. The products exported from this port are salt and ghee.

The canal on the west side of Alamparai Fort was built during the British regime in 1878 and used to exchange products with rural ships from Marakanam to Chennai until 1967. In 1750, the fortress was given to the French for the services provided by the famous French commander Dupleix to Subedar Muzaphar Jung. When the French were defeated by the British, the fort was occupied and destroyed in 1760 AD. Recently, the structure was destroyed in the 2004 Indian Ocean earthquake. The plan and section view of the Alamparai fort represented in Fig. 1. The length is $218 \mathrm{~m}$, and the width is $177 \mathrm{~m}$. The structure is mainly composed of towering free-standing brick walls that surround a huge area. A stratigraphic examination of the fort bricks carried out; it stated in detail that these bricks made between 1700 and 1750 AD. However, the compressive strength of Alamparai Fort mortar has not been explained [1]. The walls are abnormally broken and need to repair. The research on the current situation is in the starting phase.

There is no standard testing process for ancient buildings. The testing was carried out on the samples or in the empirical model of the building. It surveyed the testing process utilized for testing the historical building studied in [1]. The testing process of existing buildings is broadly classified into three categories. They are destructive, less destructive, and minor destruction to the building. The destruction testing causes damages to the building but produces an accurate result on building strength. While, in 
the other two tests, it causes less or no damage to the building. But the results are qualitative. Hence, less destruction type testing is preferred for analysing the strength of the existing building.

A study on the strength of cultural heritage buildings was performed [2]. Here, a model wall is built by using the same materials as in the cultural heritage building. Then, the cylindrical sample of two sizes, $90 \mathrm{~mm}$ and $150 \mathrm{~mm}$, was extracted from the cured wall. Then, the compression and Brazilian test took on the samples. The cultural heritage building strength analysis can perform by conducting a test on different sample sizes. The strength analysis carried out using core drilling [3]. But in this, instead of the water-cooling system, the dry air-cooling system used to cool down the core bit, while the cylinder extraction process. It reduces the failure of the samples during the test process. The strength of Cracow building analysis carried out using the core-drilling process and mathematical modelling of the test based on the material properties[4]. Here, the study was carried out only on smaller samples extracted from the building. The sample extraction process causes minor damages to the building. Based on the results, the mathematical model was realized for the analysis of a larger sample size.

The strength analysis of stone masonry was studied [5]. Here, the properties of stone, infill material, and joints analyzed by conducting in-situ and lab testing. It utilized the core drilling process to extract a sample from the Vila-Fria bridge. The study results stated that for restoring the stone masonries, a proper analysis of joint and infill materials required finding the additive agent to replicate the same strength.

A less destruction type testing called core-drilling test was performed on old brick masonry buildings [6]. Here, four samples of two different diameters, $90 \mathrm{~mm}$ and $150 \mathrm{~mm}$ extracted from the building. The first sample collected from the designed model in a laboratory. The remaining samples extracted directly from the building. The samples subjected to compression testing. The results showed that the $90 \mathrm{~mm}$ samples exhibit better mechanical strength of the building as compared to other samples.

A study on the mechanical strength of the 100-year-old Australian bridge carried out in [7]. Here, forty-five cylindrical samples of different length extracted using the core-drilling process from the bridge. The samples comprised of mortar and different joints of the building. The samples were subjected to a compression test by varying the load and split tensile strength using the Brazilian test. The results showed that the current state of the bridge is suitable for the current loading condition and exhibits good strength.

A study on the mortar strength of the current and historical building performed using a penetrometer and double punch test [8]. The penetrometer test similar to the rebound hammer test to measure the hardness of the concrete. Then, the surface disturbance zone estimated before the double punch testing process. The test results depicted that the historical building has greater mechanical strength than current building structures.

A lime mortar and clay brick wall mechanical strength was performed using three types of moderate destruction type testing in the laboratory [9]. The three testing methods are helix pull-out testing, pin-penetration test, and double punch test. Based on the test results of the wall, it observed that these tests were suitable for analysing the strength of historic buildings. The seismic analysis of Thanjavur temple carried out in [10].

Therefore, in this study, the strength of the existing materials and the blocks produced by the combination of Gur and Haritaki analyzed. The analysis found that the proposed material (Gur and Haritaki) combination has higher strength than existing materials. The fort can be reconstructed from the proposed materials. Since the Alamparai fort was repaired with the recommended materials, it remained unaffected during Hurricane Nivar.

\section{Materials And Methods}

The strength of the existing and proposed materials was analyzed based on their quality by conducting various tests. The tests are as follows:

- Analysis of properties of existing materials.

- Strength analysis of existing materials. 
- Strength analysis of proposed materials.

\subsection{Analysis of properties of existing materials}

In this, the properties of Alamparai fort studied by conducting characterization of materials, water absorption, and particle size distribution tests. These tests carried out on the ten samples collected from the building of both bedding and plastering mortar samples. The characterization of the material test indicates that the materials are rich in calcium components by having $85 \%$ of calcium oxide. It also contains high traces of other calcium components like Portlandite and aragonite presented in Fig. 8. Based on the statement from [11] about lime plaster analysis of Charminar, this high rich component is responsible for the longevity of the fort. The water absorption test indicates that the existing samples increase their weight by $15.04 \%$ after 72 -hour. The results depicted that the bricks absorb more water as time flew and reduces the building strength. The particle size distribution test described that the samples made of fine aggregate. Because the retaining of particles increases from 12-100\% as the sieve size increases from $0 \mathrm{~mm}$ to $5 \mathrm{~mm}$.

\subsection{Strength analysis of existing materials}

In this, the quality and lifetime of the current state of the Alamparai fort are studied. The rebound hammer test, core sample test and its water absorption property, and so on. The requirements and setup procedure of each test are explained in this section.

The basic test for the analysis is the compressive and flexural strength of material after 28 and 90 days of building brick from the sample collected from the Alamparai fort. Another method for measuring the compressive strength is the rebound hammer test. The rebound hammer test carried out as per IS 13311 (Part 2) - 1992 [33] by using a rebound hammer. This test depicts the quality of the hardened mortar by applying pressure to the building through a device [12]. The device made up of spring material, so it rebounds to the value based on the hardness of the concrete. The quality of the concrete is weak if it has a low rebound value and vice versa.

A non-destructive method for finding the compressive strength depicted in Fig. 2.a by using the Schmitt hammer. The rebound hammer test carried out in all four directions (i.e., East, west, North and South) of the Alamparai fort. The compressive strength for each direction of the wall is as follows 17.45 Mpa, 37.88 Mpa, 33.51 Mpa and 42.70 Mpa. The compressive strength varied between $11.40 \mathrm{Mpa}$ and $42.70 \mathrm{Mpa}$. Among these, the east-facing wall has minimum strength; due to the bombasts and struck by high waves during cyclones and tsunamis. It indicates that the east-facing wall requires restoration to retain the shape of the Alamparai fort.

The strength of the historical materials of the Alamparai fort analysed by conducting Brazilian tests like the core-drilling test and double punch test on the materials collected from it.

\subsubsection{Core- drilling test:}

In this, the core drilling test carried out in a horizontal direction (i.e., perpendicular to the direction of the wall) using a core bit of size $90 \mathrm{~mm}$ in diameter. As the drilling progresses, the bit gets hotter. To cool down the bit, the air cooling with aspirator used instead of a water- cooling system. The water- cooling system leads to the absorption of water in the building, which degrades the building strength. This degradation avoided by the air-cooling system. Another advantage of this system; it utilizes the aspirator, which cleans the dust from the drilling. Because the accumulation of dust to the specimen also degrades the evaluation process. Here, the core drilling extracts four samples from the Alamparai fort from four directions of the wall. The diameter and height of each block; are the same as $90 \mathrm{~mm}$ and $200 \mathrm{~mm}$ respectively.

The process of extracting the sample from the Alamparai fort of size $90 \mathrm{~mm}$ in diameter and $200 \mathrm{~mm}$ in height depicted in Fig. 2. (b) and it is the same for all other samples. Some of the blocks break down during the testing process displayed in Fig. 2. (d); it is due to the dust accumulation during the drilling process. The final core samples for testing displayed in Fig. 2.(c); it collected by cooling the bit step by step and clean the bit frequently using an aspirator. Then, the obtained core samples subjected to the young modulus test and water absorption test to analyse their strength. 
Additional to the compressive strength, the stress- strain behavior including the post-cracking behavior was determined. Dividing the applied force by the cross-sectional area, and dividing the mean of both longitudinal displacements by the height of the test specimen, respectively, leads to the stress-strain relations of five specimens plotted in Fig. 3(a). Both the compression strength and stiffness exhibit a large dispersion, and also the ductility behavior is different for each tested specimen. While both the red and the black stress-strain relation indicate large deformation ability, the three other curves show brittle fracture. The physically meaningless decrease of the compressive strain at the end of the black curve is the result of a tipping of the specimen (note that the displayed strain is derived from the mean of two displacements recorded at opposite surface points). All test specimens show an almost linear stress-strain behavior up to the compressive strength. However, no pronounced hardening such as in concrete can be observed. Two further displacement transducers recorded the lateral displacement to obtain information on Poisson's ratio v, which represents the quotient of the mean lateral to the mean longitudinal deformation. In Fig. 3 (b) for five tests Poisson's ratio is plotted against the compressive strain in the elastic range of deformation from $1-2 \%$. For the considered brick specimens, Poisson's ratio is relatively small between 0.05 and 0.12 . Table 1 presented in material parameters of the core samples.

Table 1

Material Parameters of the core samples

\begin{tabular}{|c|c|c|c|c|c|c|}
\hline Samples & $\begin{array}{l}\text { Size of the core } \\
\text { cylinder } \\
(\mathrm{mm})\end{array}$ & $\begin{array}{l}\text { Density } \\
(p) \\
\left(\mathrm{Kg} / \mathrm{m}^{3}\right)\end{array}$ & $\begin{array}{l}\text { Young modulus } \\
\text { (E) } \\
\text { (Mpa) }\end{array}$ & $\begin{array}{l}\text { Poisson } \\
\text { Ratio }(\mu)\end{array}$ & $\begin{array}{l}\text { Shear modulus } \\
\text { (G) } \\
\mathrm{N} / \mathrm{mm}^{2}\end{array}$ & $\begin{array}{l}\text { Shear Wave velocity } \\
\text { (Vs) } \\
\mathrm{m} / \mathrm{s}\end{array}$ \\
\hline I & $90 \varnothing \&$ & 2113.42 & 1460 & 0.13 & 624 & 544 \\
\hline II & $200 \mathrm{H}$ & 2021.72 & 1502 & 0.14 & 626 & 557 \\
\hline III & & 1985.25 & 1400 & 0.16 & 604 & 551 \\
\hline
\end{tabular}

After performing the young's modulus test on the core samples, it subjected to the water absorption test. The initial weight of the core samples before the water absorption test is $2.796 \mathrm{~kg}, 2.824 \mathrm{~kg}, 2.678 \mathrm{~kg}$ and $2.972 \mathrm{~kg}$. The water absorption carried out by immersing the samples into the water for 3 days. At the end of each day, its weight measured to determine the amount of water absorbed by the brick. Each core samples increase its weight by $9.58 \%, 9.8 \%, 9.63 \%$ and $13.05 \%$ after 24 hours. At the end of three days, the total weight of the samples increased by $10.15 \%, 10.45 \%, 10.34 \%$ and $16.76 \%$.

\subsubsection{Small scale Masonry test}

The strength of the mortar joints analysed by small scale masonry test. Here, the mortar joint between two bricks used for the testing purpose. The joint subjected to the uniaxial compression test as in the Fig. 4 (a) .

The brick-mortar joint tested by applying pressure on both sides of the bricks. Three different colours in Fig. 4 (b) indicate the Stress-displacement curve caused in the brick-mortar joint due to the uniaxial stress on the three different samples from the Alamparai fort. Both uniaxial compression tests were conducted on specimens consisting of two bricks of $4 \mathrm{~cm}$ edge and a mortar joint with thickness of $10 \mathrm{~mm} \& 20 \mathrm{~mm}$, respectively. The displacement is higher when the pressure applied to the joint increases. Based on the statement from [13] the cracks in the heritage structure is due to the triaxial pressure developed in the brick, it makes the joint weakens and reduces its strength; it gets a crack on the outer part of the wall.

\subsubsection{Double Punch test}

The double punch test is an important method to analyse the mortar strength in historical buildings by following the DIN 185559:1999 standard [14]. Here, the test carried out by applying a load of $4 \mathrm{KN}$ cell using a compressive machine of two special punching devices to the mortar extracted from the building. It is also a uniaxial strength test and it causes cracks in the mortar as in the Fig. 4 (c). The crack occurs due to the triaxial pressure developed during the test process on a smaller area of mortar. The mortar specimen height used in the DPT tests was equal to the bed point thickness, as per DIN18555-9 standard the mortar 
specimen dimension were approximately $50 \mathrm{~mm}$. The strength $(\sigma)$ for producing the crack during the DPT can be calculated using Eq. 1.

$$
\sigma=\frac{F \max }{\pi r^{2}}
$$

Where $F_{\max }$ is the maximum experimental load and radius is ten millimetres. Based on this, the double punch test carried out on five samples extracted from four directions of the wall (i.e., East, west, north and south) from the Alamparai fort. The corresponding mortar thickness and its compression strength tabulated in Table 2 and Fig. 4 (c); shows that the sample got cracks when the maximum load applied to it.

Table 2

DPT analysis of existing mortar samples

\begin{tabular}{|c|c|c|c|c|c|c|c|c|c|c|}
\hline $\begin{array}{l}\text { Samples } \\
\text { Collection }\end{array}$ & $\begin{array}{l}\text { No of } \\
\text { samples } \\
\text { (Pcs) }\end{array}$ & $\begin{array}{l}\text { Specimen } \\
\text { Thickness } \\
(\mathrm{mm})\end{array}$ & $\begin{array}{l}\text { Average } \\
\text { Specimen } \\
\text { Thickness } \\
\text { (mm }\end{array}$ & $\begin{array}{l}\text { Avg } \\
\text { Load } \\
(\mathrm{KN})\end{array}$ & $\begin{array}{l}\text { Values } \\
\text { (Mpa) }\end{array}$ & $\begin{array}{l}\text { Avg } \\
\text { Value } \\
\text { (Mpa) }\end{array}$ & $\begin{array}{l}\text { Standard } \\
\text { Deviation } \\
\text { (values) } \\
\text { (Mpa) }\end{array}$ & $\begin{array}{l}\text { Standard } \\
\text { Deviation } \\
\text { (thickness) } \\
\text { (Mpa) }\end{array}$ & $\begin{array}{l}\text { COV } \\
\text { (Values) }\end{array}$ & $\begin{array}{l}\text { COV } \\
\text { (Tk) }\end{array}$ \\
\hline \multirow[t]{5}{*}{ East wall } & \multirow[t]{5}{*}{5} & 13.7 & \multirow{5}{*}{$\begin{array}{l}13.52 \\
(17.52)\end{array}$} & 3.68 & 1.79 & \multirow[t]{5}{*}{2.62} & \multirow[t]{5}{*}{0.66} & \multirow[t]{5}{*}{1.07} & \multirow[t]{5}{*}{0.25} & \multirow[t]{5}{*}{0.41} \\
\hline & & 15.5 & & & 2.95 & & & & & \\
\hline & & 12.5 & & & 2.92 & & & & & \\
\hline & & 13.2 & & & 1.92 & & & & & \\
\hline & & 12.7 & & & 3.52 & & & & & \\
\hline \multirow[t]{5}{*}{ West wall } & \multirow[t]{5}{*}{5} & 12.8 & 14.86 & 3.92 & 2.89 & \multirow[t]{5}{*}{3.18} & \multirow[t]{5}{*}{0.47} & \multirow[t]{5}{*}{1.66} & \multirow[t]{5}{*}{0.15} & \multirow[t]{5}{*}{0.52} \\
\hline & & 14.2 & (19.61) & & 2.65 & & & & & \\
\hline & & 16.4 & & & 2.92 & & & & & \\
\hline & & 13.7 & & & 3.92 & & & & & \\
\hline & & 17.2 & & & 3.52 & & & & & \\
\hline \multirow{5}{*}{$\begin{array}{l}\text { South } \\
\text { wall }\end{array}$} & \multirow[t]{5}{*}{5} & 11.6 & 13.68 & 3.27 & 3.68 & \multirow[t]{5}{*}{3.09} & \multirow[t]{5}{*}{0.73} & \multirow[t]{5}{*}{2.42} & \multirow[t]{5}{*}{0.24} & \multirow[t]{5}{*}{0.78} \\
\hline & & 12.7 & (18.43) & & 3.92 & & & & & \\
\hline & & 18.4 & & & 2.72 & & & & & \\
\hline & & 12.5 & & & 1.86 & & & & & \\
\hline & & 13.2 & & & 3.27 & & & & & \\
\hline \multirow{5}{*}{$\begin{array}{l}\text { North } \\
\text { wall }\end{array}$} & \multirow[t]{5}{*}{5} & 13.2 & 15.35 & 3.78 & 3.72 & \multirow[t]{5}{*}{3.87} & \multirow[t]{5}{*}{0.65} & \multirow[t]{5}{*}{2.35} & \multirow[t]{5}{*}{0.17} & \multirow[t]{5}{*}{0.61} \\
\hline & & 14.6 & (19.61) & & 3.92 & & & & & \\
\hline & & 17.7 & & & 4.72 & & & & & \\
\hline & & 12.7 & & & 2.76 & & & & & \\
\hline & & 18.5 & & & 4.27 & & & & & \\
\hline
\end{tabular}

The specimens total thickness is shown in brackets (with the gypsum caps) 
The cylindrical samples of two diameters, $90 \mathrm{~mm}$ and $120 \mathrm{~mm}$ collected from the Alamparai fort using a core drilling process. These samples subjected to a load test to determine the tensile strength of the material. In this, the load varies from $0 \mathrm{KN}$ to 35 $\mathrm{KN}$. Then, the displacements in its length and width measured using the horizontal and vertical LVDT. Based on this displacement and the load, the tensile strength calculated using formula in [16].

The tensile strength in Table 3 indicates the strength between the mortar and the brick, while in compression strength, the mortar bonding only analysed. Due to this, there is a variation between the values in tensile strength.

Table 3

Tensile strength test on core samples

\begin{tabular}{|llll|}
\hline Sample Name & Diameter and Height $(\mathrm{mm})$ & Area(mm2) & Tensile strength $(\mathrm{N} / \mathrm{mm} 2)$ \\
\hline ST-1 & $90 \& 200$ & 6362 & 0.34 \\
ST-2 & & & 0.36 \\
ST-3 & $150 \& 200$ & 17672 & 0.57 \\
ST-4 & & & 0.68 \\
\hline
\end{tabular}

\subsubsection{Marsh cone test}

The cracks in the walls cured by injecting the mortar mixture into them; restore the ancient structures. This mortar mixture should have good fluidity; it also possesses greater strength to renovate the building. The mortar mixture fluid nature studied using the Marsh cone test by following ASTM C939, EN445 standard [15]. Based on the XRD analysis, the lime is the base mortar in Alamparai fort construction. Hence, in this, the lime is mixed with two solutions. One is the water; the other is the organic water. The organic water is the admixture, which improves the strength of the building. The organic water was prepared by mixing $2.5 \%$ of both Gur and Haritaki in half a litre of water and kept aside for 15 days for the fermentation process. Then, the organic water extracted from the fermented solution.

Then, both the solutions subjected to the marsh cone test by injecting the mixture into the marsh cone as in Fig. 5 (a) upper picture and it's time for reaching the container in ; its value tabulated in Table 4.

Table 4

Marsh cone test

\begin{tabular}{|lll|}
\hline S. No & Description & Time taken to discharge (s) \\
\hline 1 & Lime + Water & 13.02 \\
\hline 2 & Lime + organic matter & 7.68 \\
\hline
\end{tabular}

As per the ASTM C939 standard, the proposed organic mixture consumes less time for discharge from the marsh cone of $7.68 \mathrm{~s}$ than $13.02 \mathrm{~s}$ for lime mixture. The minimal discharge time indicates that the proposed organic matter can fix the crack effectively in the walls of the Alamparai fort. The stability test conducted by observing zero variation in the final product between both the water and organic mixtures as per ASTM C940 standard. Because Zero variation in the mixture can exhibit the homogeneity property as it hardened in future. Based on this, the Fig. 5(a) shows that the proposed organic mixture exhibit homogeneity between both the mixtures. Therefore, the proposed organic solution can restore the Alamparai fort. Then, the proposed organic matter subjected to different tests to evaluate its strength.

\subsubsection{Diagonal shear test}


The proposed Gur and Haritaki mixed in different proportions with lime and sand to form a mortar mixture. By using this mixture, the square block is built up to perform the diagonal shear test. The diagonal shear test carried out on the square shape block by applying the load in vertical direction from the top side and its force transmitted to the bottom side as in Fig. 5 (b) and it has two displacement transducers attached in horizontal and vertical directions to measure the variations in length and width of the block. Based on the displacement values from the transducers and the formulas used in [16] utilized to calculate the shear stress, shear strain, rigidity modulus and tensile strength and these values tabulated in Table 5.

Table 5. Material properties of Diagonal shear test

\begin{tabular}{|c|l|l|c|c|c|c|}
\hline Samples & $\begin{array}{l}\text { Density } \\
(\mathrm{p}) \\
\mathrm{Kg} / \mathrm{m}^{3}\end{array}$ & $\begin{array}{l}\text { Young } \\
\mathrm{N} / \mathrm{mm}^{2}\end{array}$ & Modulus (E) & Poisson Ratio ( $\mathrm{\mu})$ & $\begin{array}{l}\text { Shear } \\
\text { Modulus } \\
\mathbf{N} / \mathrm{mm} \mathbf{( G )}\end{array}$ & $\begin{array}{l}\text { Shear Wave Velocity } \\
\text { Vs } \\
(\mathrm{m} / \mathbf{s})\end{array}$ \\
\hline I & 1812 & 554 & 0.17 & 237 & 361 \\
\hline II & 1811 & 595 & 0.17 & 254 & 375 \\
\hline III & 1792 & 527 & 0.17 & 225 & 355 \\
\hline I & 1812 & 554 & 0.17 & 237 & 361 \\
\hline
\end{tabular}

Based on these values, the deflection of the building versus load is plotted in Fig. 5 (c) and it shows that as the load progresses, the deflection of the building tends to increases and it may result in deformed state of the building. All the above strength analysis performed only on the walls of the Alamparai fort. The main block arch of the fort is not analysed. Most of the historical architecture also carried out analysis only on the walls and block of the building. Hence, in this, the arch analysis conducted by performing the seismic analysis using Ansys software.

The purpose of modal analysis to analyse the behaviour of the building under seismic conditions. During seismic conditions, the building gets excited; it gets damaged when the earthquake frequency exceeds its natural frequency. The results from the strength of the core samples (Poisson ratio, shear strain and stress and young's Modulus), the modal analysis of the conical arch carried out using Ansys software. Then, it subjected to vibrations of different frequencies as tabulated in Table 6.

Table 6

Seismic analysis of arch and Fort

\begin{tabular}{|lll|}
\hline \multicolumn{3}{|c|}{ Frequency $(\mathrm{Hz})$} \\
\hline Mode & Arch` & Fort \\
\hline 1 & 2.7783 & 0.91447 \\
2 & 4.6342 & 1.6496 \\
3 & 6.9002 & 2.0362 \\
\hline 4 & 127.05 & 2.7328 \\
\hline 5 & 135.88 & 2.8298 \\
\hline 6 & 186.49 & 3.7596 \\
\hline 7 & 214.33 & 3.865 \\
\hline 8 & 218.94 & 4.386 \\
\hline 9 & 289.7 & 4.4231 \\
\hline 10 & 310.14 & 4.9585 \\
\hline
\end{tabular}

Page $8 / 25$ 
The arch gets excited about each frequency, but its shape deformed when it excited two modes, mode $5 \&$ mode 8 . During these two modes, 5 and 8, the arch gets to deform towards the right or left direction, as in Fig. 6 (a) to (h). The individual responses of the building concerning the time of the vibrations displayed in Fig. 7 (a) to (f).

The above responses are the existing material-based arch response during seismic frequency ranges from $2 \mathrm{~Hz}$ to $310 \mathrm{~Hz}$. The peaks in the response curve indicate the natural or cut-off frequency of the arch. The term cut-off frequency indicates the starting frequency for building deformation. Based on the response curve for all conditions like acceleration to stress, the building gets deform after mode 5 . because the values get reduced at this point. Therefore, the strength of the arch also analyzed by this seismic analysis.

The above strength analysis determines that the Alamparai Fort requires a restoration process to restore its historical heritage for longer periods. Based on the stability tests results, the Gur and Haritaki used in mortar mixture with lime to restore the fort.

\section{Characterization Techniques}

\subsection{Acid loss test}

The acid dissolution test [17] found that the sufficient ratio of lime mortar and sand mixture for the sample is 1:3 (Lime: Fine aggregate) from Table 7. The wet chemical analysis determines the Binder-Aggregate ratio $\left(B / A_{g}\right)$. It found that the former part containing calcium, magnesium, $\mathrm{Al}_{2} \mathrm{O}_{3}, \mathrm{Fe}_{2} \mathrm{O}_{3}$, and soluble silica. Based on $\mathrm{CaO}$ to $\mathrm{MgO}$ ratio, determined the type of binder (Calcific /dolomitic).

Table 7

Results on Acid Loss test

\begin{tabular}{|lllllll|}
\hline $\begin{array}{l}\text { Sample } \\
\text { ID }\end{array}$ & $\begin{array}{l}\text { Initial Weight } \\
(\mathbf{g})\end{array}$ & $\begin{array}{l}\text { Acid } \\
\text { loss }(\mathbf{g})\end{array}$ & $\begin{array}{l}\text { Weight after acid } \\
\text { loss }(\mathbf{g})\end{array}$ & $\begin{array}{l}\text { Weight of sand retained } \\
\mathbf{( g )}\end{array}$ & $\begin{array}{l}\text { Weight of binder } \\
\mathbf{( g )}\end{array}$ & $\begin{array}{l}\text { B/A } \\
\text { ratio }\end{array}$ \\
\hline F-1 & 100 & 7.2 & 92.8 & 68.6 & 24.2 & $1: 2.83$ \\
\hline F-2 & 100 & 7.9 & 92.1 & 69.4 & 22.7 & $1: 3.05$ \\
\hline F-3 & 100 & 7.4 & 92.6 & 71.2 & 21.4 & $1: 3.33$ \\
\hline F-4 & 100 & 7.3 & 92.7 & 69.9 & 22.8 & $1: 3.03$ \\
\hline F-5 & 100 & 6.9 & 93.1 & 68.42 & 24.68 & $1: 2.77$ \\
\hline
\end{tabular}

The mechanical characteristics of mortars rely upon the binder type and its mix ratio $[18,19]$ addressed that in accommodating lime mortar pores, the $\mathrm{B} / \mathrm{A}$ is a critical parameter and directly affects disseminating $\mathrm{CO}_{2}$ in the lime matrix. In his ten books of architecture, Vitruvius, chapter IV [20] claimed that lime mortar of 1: 3 mix ratio is excellent for higher carbonation. The ancient architects, which were constructed with $\mathrm{B} / \mathrm{Ag}$ of $1: 3$, achieved the higher strength and toughness. The consumption of $\mathrm{CO}_{2}$ to form $\mathrm{CaCO}_{3}$ makes it an environmentally friendly building material during its healing and hardening process [21].

\subsection{XRD and XRF analysis of lime mortar}

XRD results mainly depict the carbonation process's speed in the calcium present in the lime mortar shown in Fig. 8. Under high pressure, orthorhombic crystalline aragonite (fibrous) is formed, and the vaterite with a unique structure is the most unstable polymorph of $\mathrm{CaCO} 3$ [22]. The primary compound is calcite, which is found abundantly in both plaster and binder mortar, indicating the utilization of the lime in the mortar $[23,24]$ The carbonation process's speed is visualized by having high $\mathrm{CaCO}_{3}$ components like calcite and Portlandite, and aragonite. Therefore, the aggregate of the mortar is not carbonized, that is, the 
siliceous aggregate, the peaks of calcite and aluminum silicate may come from the binder. Therefore, the binder may be air lime with $\mathrm{CaCO}_{3}$ and $\mathrm{Al}_{2} \mathrm{O}_{3}$ impurities.

In Table 8, the chemical properties of lime mortar samples are analysed by the XRF process, the hydraulic and cementation index values are measured. and are confined to the 0.05 to 0.12 and 0.10 to 0.12 range [20]. Hence, the binder is categorized as air lime. The lime mortar sample AAF1 achieved a better cementation index. Owing to brick in the lime mortar, it attributed with a low amount of clay minerals. The clay bricks have a high amount of calcite and aluminium oxides [25]. The load-bearing calcium carbonate compound may have resulted in a high percentage of calcium oxide. The presence of silica and aluminum oxides may be beneficial for the pozzolanic action of lime mortar. The samples' study found out that air lime mortars were used to build the fort of Alamparai. Therefore, in the proposed, the air lime can be used as the mortar mixture base.

Table 8

XRF Results of Samples

\begin{tabular}{|lllllllllll|}
\hline Samples & $\mathrm{CaO}$ & $\mathrm{Al}_{2} \mathrm{O}_{3}$ & $\mathrm{MgO}$ & $\mathrm{Fe}_{2} \mathrm{O}_{3}$ & $\mathrm{SiO}_{2}$ & $\mathrm{SO}_{3}$ & $\mathrm{~K}_{2} \mathrm{O}$ & $\mathrm{HI}$ & $\mathrm{Cl}$ & LOI \\
\hline $\mathrm{F}-1$ & 85.23 & 0.82 & 1.28 & 1.74 & 2.43 & 0.96 & 0.24 & 0.13 & 0.19 & 25.28 \\
$\mathrm{~F}-2$ & 82.43 & 3.97 & 0.86 & 1.96 & 0.46 & 1.27 & 0.36 & 0.12 & 0.13 & 19.78 \\
$\mathrm{~F}-3$ & 84.59 & 1.16 & 0.7 & 1.68 & 0.3 & 0.17 & 0.24 & 0.11 & 0.04 & 16.72 \\
\hline
\end{tabular}

\subsection{SEM analysis}

The SEM test is carried out on the mortar samples to evaluate the hardening process. The calcium carbonate is present in the mixture is seen from the SEM analysis, and the voids found in the mix are explained. Figure 9a to Fig. 9b is the SEM results of the plaster sample with lime mortar mixture. It shows that there is a large calcite formation as well as it has voids in it. This void is responsible for letting water and forming cracks.

Similarly, Fig. 9. c to Figure d. his the results for bedding mortar sample mix, and it also shows the presence of cracks and good calcite formation. The existence of organic admixtures has modified the texture and microstructure of calcite and vaterite. Vaterite rhombohedra crystals [26] are formed due to the presence of organic substances [27]. Carbohydrates strengthen the loose structures, leading to improve strength and durability. Therefore, both plaster and mortar samples show good calcite formation but cracks in it. Hence, the additive should be chosen with a higher carbonation process and lesser voids to avoid damages and let water into the building.

\subsection{FTIR Interpretation}

The FTIR graphs of the various samples are presented in Figs. 10. The FTIR analysis was carried out to determine the mixture's carbonation process, similar to the XRD analysis. In FTIR, the detailed analysis of components is studied to select the perfect additive agent for the restoration. This analysis is also carried out on the residuals of the acid dissolved test. The characteristic peaks of plaster mortar at $3920 \mathrm{~cm}^{-1}, 3889 \mathrm{~cm}^{-1}, 3805 \mathrm{~cm}^{-1}$ and $1630 \mathrm{~cm}^{-1}$ indicates proteins, peak at $1815 \mathrm{~cm}^{-1}, 1445 \mathrm{~cm}^{-1}$ $, 1795 \mathrm{~cm}^{-1}, 1636 \mathrm{~cm}^{-1} 879 \mathrm{~cm}^{-1}$ and $872 \mathrm{~cm}^{-1}$ indicates calcites [27], $1045 \mathrm{~cm}^{-1}$ indicates carbohydrates, $618 \mathrm{~cm}^{-1}$ indicates aragonite and $784 \mathrm{~cm}^{-1}$ indicates $\mathrm{O}-\mathrm{C}-\mathrm{O}$ in-plane bending.

The range of $1114 \mathrm{~cm}^{-1}$ indicates carbohydrates [28], $599 \mathrm{~cm}^{-1}$ indicates aragonite, and $784 \mathrm{~cm}^{-1}$ indicates $0-C-0$ in-plane bending. From the peaks, it is observed that the mortar-based samples have higher carbohydrates as compared to plaster. Due to this, the formation of calcite is higher in plaster as compared to the mortar-based samples. Therefore, in the FTIR results, as shown by XRD, organic matter such as carbohydrates and proteins, and clay impurities such as silica, alumina and ferrous oxide can be verified. The broad peak at $3730 \mathrm{~cm}-1$ and the hydroxide ion stretching showed isopropanol, ethanol and $\mathrm{CaO}$ not found in the XRD results.

\subsection{TGA DTA analysis}

Page $10 / 25$ 
TG-DTA analysis also followed the findings acquired from XRD, SEM, EDS, and FT-IR. In Fig. 11, a dramatic change in weight was $27 \%$ between $600^{\circ} \mathrm{C}$ and $800^{\circ} \mathrm{C}$, primarily because of the calcite de-carbonation. The findings of the TG study are therefore well in line with the SEM and XRD outcomes. A heavy peak at $470^{\circ} \mathrm{C}$ in the adjusted sample shows aragonite available, while no such peak was found, as shown in Fig. 11 [29]. A little exothermic peak for F-2 at $515^{\circ} \mathrm{C}$ demonstrates vaterite presence [30].

The calcium hydroxide dehydration and DTA curve presence of aragonite, vaterite was compatible with the XRD analysis results. In the sample of $\mathrm{F}-2$, the low and short peak from $700^{\circ} \mathrm{C}$ to $900^{\circ} \mathrm{C}$, the mild endothermic peak at $680^{\circ} \mathrm{C}$ from $600^{\circ} \mathrm{C}$ to $800^{\circ} \mathrm{C}$ is the $\mathrm{CO}_{2}$ escape during structural disintegration, and calcite breakdown in Fig. 11 [29]. Organic substances have been confirmed by FT-IR analysis and organic tests and clarified behind the polymorphs of $\mathrm{CaCO}_{3}$ formation. Based on the $\mathrm{CO}_{2}$ weight loss, the amount of calcium carbonate is determined. F-2 (33 percent) reported a high level of precipitated calcium carbonate in the lime mortar samples, followed by F-1 (27\%) and F-2 (19\%).

\subsection{Strength analysis of proposed materials \\ 3.6.1 chemical characteristics of lime}

The chemical composition of lime-like calcium oxide, magnesium oxide, iron oxide, silica, alumina, and their importance on the behaviour of lime are dissected to find out the lime class as per IS 6932 (Part I)-1973 [31]. The chemical compounds present in the Air lime are $\mathrm{CaO}$ of $90.82 \%, \mathrm{MgO}$ of $0.001 \%, \mathrm{SiO}_{2}$ of $4.648 \%, \mathrm{Al}_{2} \mathrm{O}_{3}$ of $2.242 \%, \mathrm{Fe}_{2} \mathrm{O}_{3}$ of $2.289 \%$, and insoluble residues of $6.49 \%$, Loss on Ignition of $21.58 \%$.

Based on XRF results, the lime could be categorized as high calcium lime with a CaO content of $90.821 \%$. As per IS: $712-1984$ [32], we could use the lime for structural purposes like bedding, mortar, and plasters. The lime's elemental composition is shown in Table 9 and shows that the lime's oxygen content is high. Because of this higher oxygen, relative to the calcites, Portlandite formation would be more significant. It is observed that the Portlandite is higher as compared to the calcium carbonate components like calcium oxide and calcite and brucite in Table 9. Calcite is stable and has a hexagonal structure at average temperature. Aragonite is formed under high pressure, while vaterite stone is a relatively unstable polymorph of $\mathrm{CaCO}$ [33].

Table 9. Minerals identification of simulated Lime

\begin{tabular}{|l|c|c|c|c|}
\hline Minerals & Calcium Oxide (CaO) & $\begin{array}{c}\text { Portlandite } \\
\text { (P) }\end{array}$ & $\begin{array}{c}\text { Calcite } \\
\text { (C) }\end{array}$ & $\begin{array}{c}\text { Brucite } \\
\text { (B) }\end{array}$ \\
\hline Intensity & ++ & +++ & ++ & ++ \\
\hline
\end{tabular}

+++ - High Intense peaks ++ - Moderate Intense peaks

Further, the $\mathrm{CaCO}_{3}$ polymorphs occur because of the self-healing with the presence of $\mathrm{Mg}$. Due to low Calcite formation, the carbonation is lesser in ordinary lime mortar. Hence, an additive agent is required to improve the carbonation process.

The experimental analysis of sample materials from the Alamparai fort observed that the fort made up of calcium-rich and finesized element. According to IS 712-1984 [32], the air lime used as the base for mortar mixture in existing material. Hence, in the reconstruction of materials also the air lime used as the base mortar. The XRD and XRF analysis of materials indicate that composed of a calcium-rich element exhibit greater strength. Hence Gur and Haritaki used as a binding agent to mortar mixture for restoring the Alamparai fort. The tannic acid present in Haritaki exhibits greater strength due to its stronger bond between the elements. Hence, the proposed binder agent can restore the fort effectively as the same as the existing materials. The lime and sand mixed in a ratio of 1:3 as per IS standards [32]. The Gur and Haritaki mixed in equal ratio to the base mortar. The Gur and Haritaki ratio varied from $2.5-12.5 \%$ to analyze its strength and find the right proportion for restoration.

The proposed mortar mixture moulded into a brick of $50 \mathrm{~mm} \times 50 \mathrm{~mm} \times 50 \mathrm{~mm}$ size. Then, the moulded brick subjected to compressive and flexural strength by applying a low amount of pressure on it. Both compressive and flexural strength observed for two time periods. One is 28 days; the other is 90 days. The compressive strength of different samples for 28 days was 1.65 $\mathrm{N} / \mathrm{mm} 2,1.72 \mathrm{~N} / \mathrm{mm} 2,1.92 \mathrm{~N} / \mathrm{mm} 2,2.15 \mathrm{~N} / \mathrm{mm} 2$ and $2.94 \mathrm{~N} / \mathrm{mm} 2$. At the end of 90 days, its strength improved by 1.84 $\mathrm{N} / \mathrm{mm} 2,2.48 \mathrm{~N} / \mathrm{mm} 2,2.44 \mathrm{~N} / \mathrm{mm} 2,2.56 \mathrm{~N} / \mathrm{mm} 2$ and $3.96 \mathrm{~N} / \mathrm{mm}^{2}$. The hardened mortar increases its compressive strength by

Page $11 / 25$ 
$1.5 \%$ from its initial value as time progresses. Similarly, the flexural strength for the proposed mortar samples also calculated. It is conducted by applying low pressure on the brick of $160 \mathrm{~mm} \times 40 \mathrm{~mm} \times 40 \mathrm{~mm}$. The flexural strength also improved its strength at the end of ninety days as $0.86 \mathrm{Mpa}, 0.86 \mathrm{Mpa}, 0.94 \mathrm{Mpa}, 0.96 \mathrm{Mpa}$ and $1.3 \mathrm{Mpa}$ for different mortar mixture samples.

\subsubsection{Comparison between proposed and existing mortar sample}

The brick sample obtained from the fort is of size $215 \mathrm{~mm} \times 103 \mathrm{~mm} \times 35 \mathrm{~mm}$, and the same size of simulation brick is testing for estimation of the water absorption rate. Nearly four brick samples to use for testing [10]. From the brick water absorption results, it shows that the old brick absorption rate was $10.65 \%, 10.70 \%, 8.29 \%, 10.49 \%$ at 24 hours and $12.57 \%, 14.63 \%, 12.95$ $\%, 14.90 \%$ at 72 hours. For the simulated bricks, the water absorption rate is $9.02 \%, 11.28 \%, 7.3 \%, 7.07 \%$ at 24 hours and $17.16 \%, 17.26 \%, 14.47 \%, 7.07 \%$ at 72 hours. The water absorption rate of the simulated brick is almost $13 \%$ less than the old brick. Due to the presence of protein content in the Jaggery - Kadukkai, excellent water repellent coating to the brick. Overall, the proposed Jaggery - Kadukkai based mortar is excellent in terms of strength and water resistance. Therefore, the restoration using the proposed mortar provides longer durability of the conditions with great strength.

The proposed materials subjected to a water absorption test; the results indicate that it increases their weight by $7.07 \%$ only after 72-hour. Therefore, the proposed Gur and Haritaki based mortar can increase the lifetime of the fort by absorbing less water.

\section{Modelling And Analysis Of Proposed Organic Materials}

In this, the results of both the existing and proposed mortar sample analysed to identify the quality of the material.

\subsection{Conical vault arch testing}

The Alamparai fort consists of arches that could not access by using the core drilling process; it causes damage to the building during the block extraction process. Hence, most of the historical analysis does not perform strength calculation on the arches. Therefore, the arch test has done in this paper by constructing the arch as in the fort using the proposed binding agent. The measurements for the arch construction taken from the fort as depicted in Fig. 12.

Based on the arch measurements from the fort, the front view of the arch shows that it has $40 \mathrm{~cm}$ in total height; $21 \mathrm{~cm}$ height from the inner arch. The radius of the inner arch from its centre is $39 \mathrm{~cm} ; 60 \mathrm{~cm}$ radius for the outer arch depicted in Fig. 12.(a). Similarly, the width between the inner and outer arch measured as $21 \mathrm{~cm}$ from the back view. The total height is $60 \mathrm{~cm}$, then the radius of the outer arch is $75 \mathrm{~cm}$ from the arch centre. Using front and back view arch measurements, the arch built up for three different proportions of organic matter-based mortar mixture built as in Fig. 12.(b), then the sand load test carried out on the arch for the strength analysis.

The above conical arch subjected to the sand load test to analyse its strength on heavy loads experimentally. Similar measurements used for the seismic analysis of the arch using Ansys software.

\subsection{Experimental analysis of Sand load test on arch}

Here, the arch built using Gur and Haritaki mortar mixture; it cured for ninety days to gain its maximum compressive strength. Then, the cured arch subjected to the load test by applying the sandbag on the top of the arch as in Fig. 12.c. Here, the load varies from $0 \mathrm{KN}$ to $25 \mathrm{KN}$. During this process, the deformation of the arch measured using five transducers to measure the displacements in the horizontal left, right and centre and along the left and right side of the arch quarters.

Based on the displacement measurements from the transducers, the relation between the load and displacement realized in the graphical view in Fig. 13.(a) to Fig. 13.(c) for three different mortar proportions. 
The results show that mortar mixture 3 has higher strength by having minimum displacement. Whereas in other mortar composition, it exhibits $3 \mathrm{~mm}$ displacement for the same load, while in mortar mixture 3 , its overall displacement itself below 3 $\mathrm{mm}$. By experimental analysis of load test on the arch indicates that the proposed organic Gur and Haritaki is suitable for restore the Alamparai fort.

\subsection{Modelling and seismic Analysis of Alamparai fort using Ansys software}

The purpose of modal analysis to analyse the behaviour of the building under seismic conditions. During seismic conditions, the building gets excited; it gets damaged when the earthquake frequency exceeds its natural frequency. By using, the diagonal shear test results (Poisson ratio, shear strain and stress and young's Modulus), the modal analysis of the conical arch carried out using Ansys software. The realization of each wall of Alamparai fort shown in the figure

In each wall of the fort, it has two full conical arches and two half conical arch. The fort entrance placed on the north side wall; its width is $176.40 \mathrm{~cm}$. The North and south sidewall height is $7.60 \mathrm{~cm}$ from the ground to the arch starting point; the east and west sidewall height is $7.0 \mathrm{~cm}$. The total wall width split between the arches and their centres.

Then, it subjected to vibrations of different frequencies as tabulated in the Table 6. The arch gets excited about each frequency, but its shape deformed when it excited after mode 2.

During these two modes, 7 and 10, the arch gets deform towards the south or west wall, as in Fig. 14. The individual responses of the building concerning the time of the vibrations displayed in Fig. 15 (a) to Fig. 15 (h).

The above responses are the existing material-based arch response during seismic frequency ranges from $0.9 \mathrm{~Hz}$ to $4.95 \mathrm{~Hz}$. The peaks in the response curve indicate the natural or cut-off frequency of the arch. The term cut-off frequency indicates the starting frequency for building deformation. Based on the response curve for all conditions like acceleration to stress, the building gets deform after mode 2 . because the values get reduced at this point. Therefore, the strength of the arch also analyzed by this seismic analysis.

Based on the strength and seismic analysis of the proposed and existing materials, the proposed Gur and Haritaki materials are suitable for restoring the fort. Because it exhibits high compressive strength after 90 days and lesser displacement in both sandload test and seismic analysis test.

\section{Discussion}

In general, it is difficult to characterize the mechanical properties of existing mortars in historic buildings by minimizing the damage caused during inspections. In any case, the samples taken from the building should be small enough to minimize aesthetic interference, retain the original materials, and avoid the risks and difficulties associated with changing structural members. A small sample can be taken based on the value of the structure and then taken to the laboratory to obtain a direct estimate of the material's properties.

In this paper, the response spectrum method and time history analysis method are used to carry out seismic analysis on the Alamparai fort and arch in Tamil Nadu, India. The research carried out helps to better understand the behavior of the structure and the most susceptible elements of the structure in any seismic event. The uncertainty of material properties and geometric details has been resolved through comprehensive parameter studies. It is worth noting that although structural modeling is greatly simplified, different structural analysis methods can still make similar inferences about the seismic response of fortresses and arches. Some important inferences from current research can be listed as follows:

- Conduct structural analysis of historical buildings to better understand structural behavior and/or to obtain residual capacity during structural evaluation, and to develop strengthening strategies when necessary

- Modal analysis shows that fortresses and arches are the most vulnerable parts of the structure. The aggravated response under seismic excitation is due to its high fundamental frequency.

Page $13 / 25$ 
- Lime mortar is used extensively in the fort. Although the strength is lower, the deformability is higher than other adhesive materials. Therefore, the structure can be expected to have more energy dissipation capacity, which is beneficial to dynamic loads.

- The destruction of the structure evolved from the destruction of the material, and due to its advantageous configuration (pyramid shape), instability should not be a problem. The natural frequency $(0.9-4.9 \mathrm{~Hz})$ is completely separated from the fundamental frequency of the soil $(2.8-311 \mathrm{~Hz})$, indicating that there is no possibility of resonance.

\section{Conclusion}

Heritage structure restoration can take place only by analysing the properties of existing structures. Based on the existing structure properties, the alternative binding agent selected; can regain the same strength and shape of the heritage structures. Based on these, the restoration of Alamparai fort performed by analysing the fort materials using mortar strength analysis by core-drilling, double punch test and small-scale masonry test. In this, the arch properties also analysed by performing seismic analysis based on the mortar strength properties.

- The core-drilling test indicates that the East wall faces higher damages than the other walls by having lower compressive strength.

- The mortar joints in the older bricks exhibit greater strength for $20 \mathrm{KN}$ load. Therefore, the choice of binding agent should replicate this strength.

- The major arch analysis carried out in this paper by using the strength results from the core-drilling process.

- The seismic analysis of the arch indicates the building strength by showing smaller displacements.

Based on these, the stability analysis of the organic and existing materials shows that Gur and Haritaki is the best agent for restoring the fort. Hence, the mortar strength and seismic analysis of these materials performed using, diagonal shear test and seismic modelling of the fort. The proposed material strength tests results indicate that the Gur and Haritaki is the best agent to restore the fort.

- The proposed material exhibits greater strength after ninety days of cured blocks.

- The materials absorb less water than the existing materials, so it helps to increase the building's longevity.

- The proposed material produces less displacement of about $1.2 \mathrm{~mm}$ for $20 \mathrm{KN}$ loads during sand-load test and seismic analysis.

The fort restored with these materials; it survived in Nivar cyclone crossed on 26th November 2020.

\section{Declarations}

- Ethical Approval - Not Applicable

- Consent to Participate - Not Applicable

- Consent to Publish - Not Applicable

- Competing interests - The authors declare no competing interests

- Funding- Not Applicable

- Authors Contributions -

Kotteeswaran Santhanam - Conceptualization, Methodology, writing, Original draft preparation.

Ravi Ramadoss - Reviewing, Results and Discussion.

- Availability of data and materials - All data generated or analysed during this study are included in this published article.

- Acknowledgements - Not Applicable 


\section{References}

1. Arêde, A., Almeida, C., Costa, C., \& Costa, A. (2019). In-situ and lab tests for mechanical characterization of stone masonry historical structures. Construction and Building Materials, 220, 503-515.

https://doi.org/10.1016/j.conbuildmat.2019.06.039.

2. Alonso-Olazabal, A., Ortega, L. A., Zuluaga, M. C., Ponce-Antón, G., Jiménez Echevarría, J., \& Alonso Fernández, C.2020. Compositional Characterization and Chronology of Roman Mortars from the Archaeological Site of Arroyo De La Dehesa De Velasco (Burgo De Osma-Ciudad De Osma, Soria, Spain). Minerals, 10(5) :393. https://doi.org/10.3390/min10050393.

3. Barnaure, M., \& Cincu, M. (2020, March). Testing methods for assessing material properties in historical masonry structures: a review. In IOP Conference Series: Materials Science and Engineering (Vol. 789, No. 1, p. 012003). IOP Publishing. doi:10.1088/1757-899X/789/1/012003.

4. Binici, H., \& Akcan, M. 2015. The Investigation of Physical and Mechanical Properties of Mortars used in Historical Buildings in Harran (Sanliurfa, Turkey). European Journal of Engineering and Technology 3(5).

5. Bakolas, A., Biscontin, G., Moropoulou, A., \& Zendri, E. 1998. Characterization of structural byzantine mortars by thermogravimetric analysis. Thermochimica Acta, 321(1-2), 151-160. 10.1016/S0040-6031(98)00454-7.

6. Cobirzan, N., \& Balog, A.2014. Characterization of mortar compatibility using microscopical and XRD analysis. Romanian Journal of Physics, 59 : 3-4.

7. Dorji, J., Zahra, T., Thambiratnam, D., \& Lee, D. (2021). Strength assessment of old masonry arch bridges through moderate destructive testing methods. Construction and Building Materials, 278, 122391.doi: 10.1016/j.conbuildmat.2021.122391.

8. Devi, N. V. T. R. (2020). Grouting and Injection Techniques To Repair Cracks And Water Leakage At The Renuka Devi Temple, Chandragutti, India. Material In Tehnologije, 54(5), 633-642. doi:10.17222/mit.2019.250.

9. Dai, M., Peng, C., Liu, H., Wang, J., Ali, I., Naz, I., 2019. Analysis and imitation of organic Sanhetu concrete discovered in an ancient Chinese tomb of the Qing Dynasty. J. Archaeol. Sci.: Reports 26, 101918. doi.10.1016/j.jasrep.2019.101918.

10. Degloorkar, N. K., \& Pancharathi, R. K, Characterization of ancient mortar for the sustainability of an 800 -year-old heritage site in India, Materials Today: Proceedings 32(4) (2020) 734-739. https://doi.org/10.1016/j.matpr.2020.03.472.

11. Dizhur, D., Lumantarna, R., Biggs, D. T., \& Ingham, J.2017. M. In-situ assessment of the physical and mechanical properties of vintage concrete clay bricks. Materials and Structures, 50(1), 63. doi.org/10.1617/s11527-016-0939-9.

12. Furtmüller, T., Adam, C., \& Niederegger, C. (2012, September). Seismic capacity of old masonry buildings in Vienna: Laboratory testing on bricks, mortar, and small-scale brick masonry. In Proc. of the Third International Symposium on LifeCycle Civil Engineering (pp. 3-6).

13. Fiori, C., Vandini, M., Prati, S., \& Chiavari, G.2009. Vaterite in the mortars of a mosaic in the Saint Peter basilica, Vatican (Rome). Journal of Cultural Heritage, 10(2): 248-257. doi.org/10.1016/j.culher.2008.07.011.

14. Gulec, A., \& Ersen, A. (1998) characterizes ancient mortars: Evaluation of simple and sophisticated methods. Journal of Architectural Conservation, 4(1) 56-67. doi.org/10.1080/13556207.1998.10785207.

15. Ghadban, S. S., \& Ashhab, M. 2011. Stone restoration practice in palestinian territories: a case study from jerusalem. Journal of Architectural Conservation, 17(3), 75-96. doi.org/10.1080/13556207.2011.10785098.

16. IS 6932 (Part VII)-1973. Methods of tests for building limes-Determination of compressive and transverse strengths. Bureau of Indian Standards, New Delhi, India.

17. IS 712 -1984, Indian Standard Specification for Building Limes. Bureau of Indian standards, New Delhi, India.

18. IS 13311-2 (1992): Method of non-destructive testing of concret-methods of test, Part 2: Rebound hammer [CED 2: Cement and Concrete], Bureau of Indian standards, New Delhi, India.

19. Łątka, D., \& Matysek, P. (2020). Determination of Mortar Strength in Historical Brick Masonry Using the Penetrometer Test and Double Punch Test. Materials, 13(12), 2873. doi:10.3390/ma13122873.

20. Matysek, P., \& Witkowski, M. (2019). Compressive Tests of Historical Brick Masonry-Case Study of the Archduke Rudolf Caserns Buildings in Cracow. International Journal of Architectural Heritage, 1-

11. https://doi.org/10.1080/15583058.2019.1675802.

Page $15 / 25$ 
21. Marastoni, D., Pelà, L., Benedetti, A., \& Roca, P. (2016). Combining Brazilian tests on masonry cores and double punch tests for the mechanical characterization of historical mortars. Construction and Building materials, 112, 112-

127. doi:10.1016/j.conbuildmat.2016.02.168.

22. Milosevic, J., Lopes, M., Gago, A. S., \& Bento, R. (2013). Testing and modelling the diagonal tension strength of rubble stone masonry panels. Engineering structures, 52, 581-591. doi:10.1016/j.engstruct.2013.03.019.

23. Moropoulou, A., Bakolas, A., \& Bisbikou, K. 1995.Characterization of ancient, Byzantine, and later historic mortars by thermal and X-ray diffraction techniques. thermochemical Acta, 269: 779-795. doi.org/10.1016/00406031(95)025715.

24. Maravelaki-Kalaitzaki, P., Bakolas, A., Karatasios, I., \& Kilikoglou, V.2005. Hydraulic lime mortars for the restoration of historic masonry in Crete. Cement and Concrete Research, 35(8), 1577-1586. doi.org/10.1016/j.cemconres.2004.09.001.

25. Moropoulou, A., Bakolas, A., \& Bisbikou, K. 2000. Investigation of the technology of historic mortars. Journal of Cultural Heritage, 1(1), 45-58. doi.org/10.1016/S1296-2074(99)00118-1.

26. Narayanmugam, R., Subramaniam, S., \& Perumalpillai, P. (2019). Assessment Of Strength Characteristics Of A Heritage Structure-Alamparai Fort, India. International Journal of Conservation Science, 10(3).

27. Ö. Cizer, C. Rodriguez-Navarro, E. Ruiz-Agudo, J. Elsen, D. Van Gemert, K. Van Balen. 2012. Phase and morphology evolution of calcium carbonate precipitated by carbonation of hydrated lime, J. Mater. Sci. 47 (16) 6151-6165. doi.org/10.1007/s10853-012-6535-7.

28. Pelà, L., Roca, P., \& Benedetti, A. (2016). Mechanical characterization of historical masonry by core drilling and testing of cylindrical samples. International Journal of Architectural Heritage, 10(2-3), 360-374. doi:10.1080/15583058.2015.1077906

29. Pelà, L., Canella, E., Aprile, A., \& Roca, P. (2016). Compression test of masonry core samples extracted from existing brickwork. Construction and Building Materials, 119, 230-240. doi:10.1016/j.conbuildmat.2016.05.057

30. Pelà, L., Roca, P., \& Aprile, A. (2018). Combined in-situ and laboratory minor destructive testing of historical mortars. International Journal of Architectural Heritage, 12(3), 334-349. https://doi.org/10.1080/15583058.2017.1323247.

31. Ronald, J. A., Menon, A., Prasad, A. M., Menon, D., \& Magenes, G. (2018). Modelling and analysis of South Indian temple structures under earthquake loading. Sādhanā, 43(5), 1-20. doi:10.1007/s12046-018-0831-0

32. Ravi, R., Thirumalini, S., \& Taher, N. (2018). Analysis of ancient lime plasters-Reason behind longevity of the Monument Charminar, India a study. Journal of Building Engineering, 20, 30-41. doi:10.1016/j.jobe.2018.04.010

33. Rowland, I.D., Howe, T.N. (Eds.), 2001. Vitruvius: 'Ten Books on Architecture. Cambridge University Press.

34. Segura, J., Pelà, L., Roca, P., \& Cabané, A. (2019). Experimental analysis of the size effect on the compressive behaviour of cylindrical samples core-drilled from existing brick masonry. Construction and Building Materials, 228, 116759. doi:10.1016/j.conbuildmat.2019.116759.

\section{Figures}



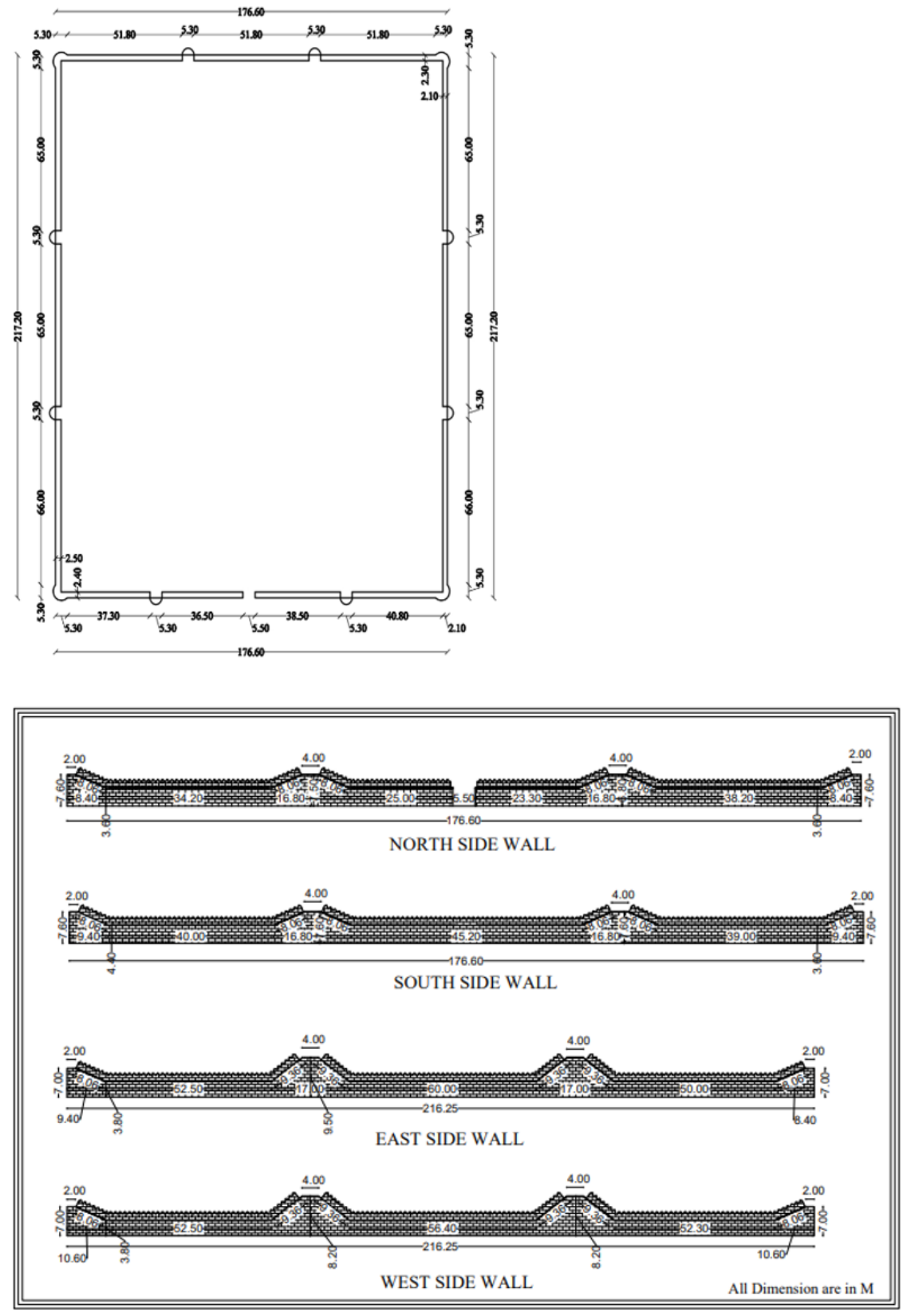

Figure 1

Plan and Section of Alamparai fort
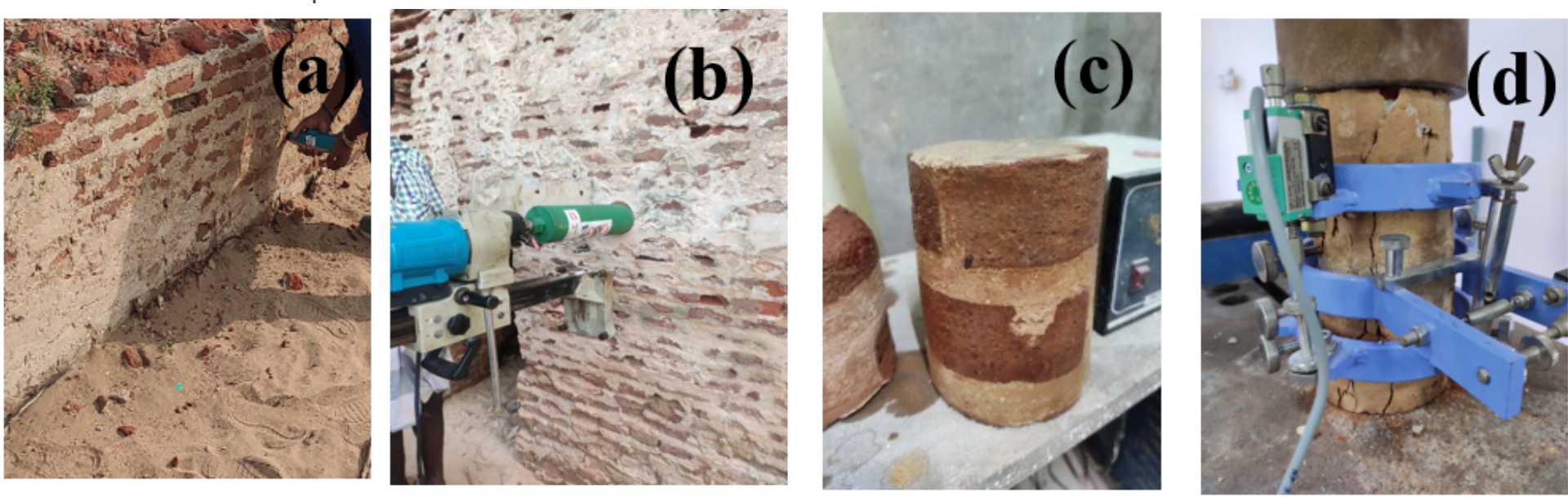
Figure 2

(a) Rebound hammer test, (b) Core drilling at north side wall, (c) Different shapes of core samples, (d) Failure of sample test
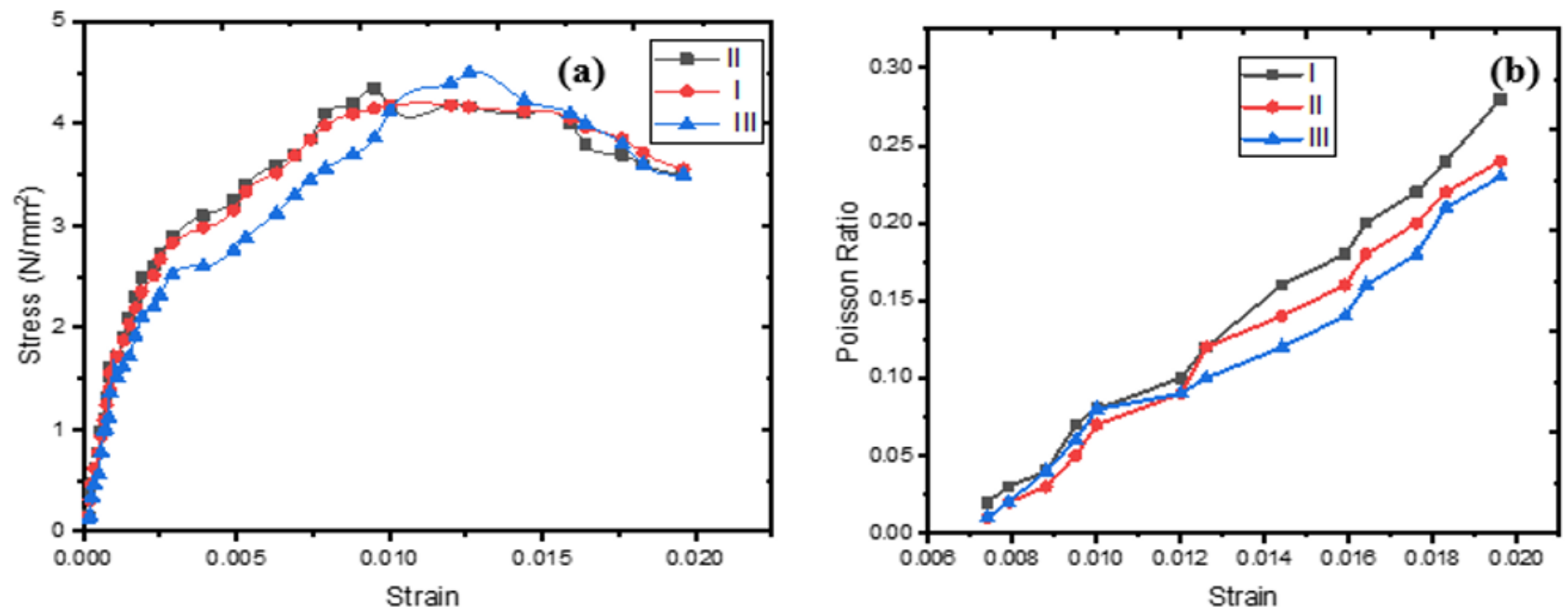

Figure 3

(a) Stress Vs Strain Curve (b) Poisson Ration Vs Strain Curve
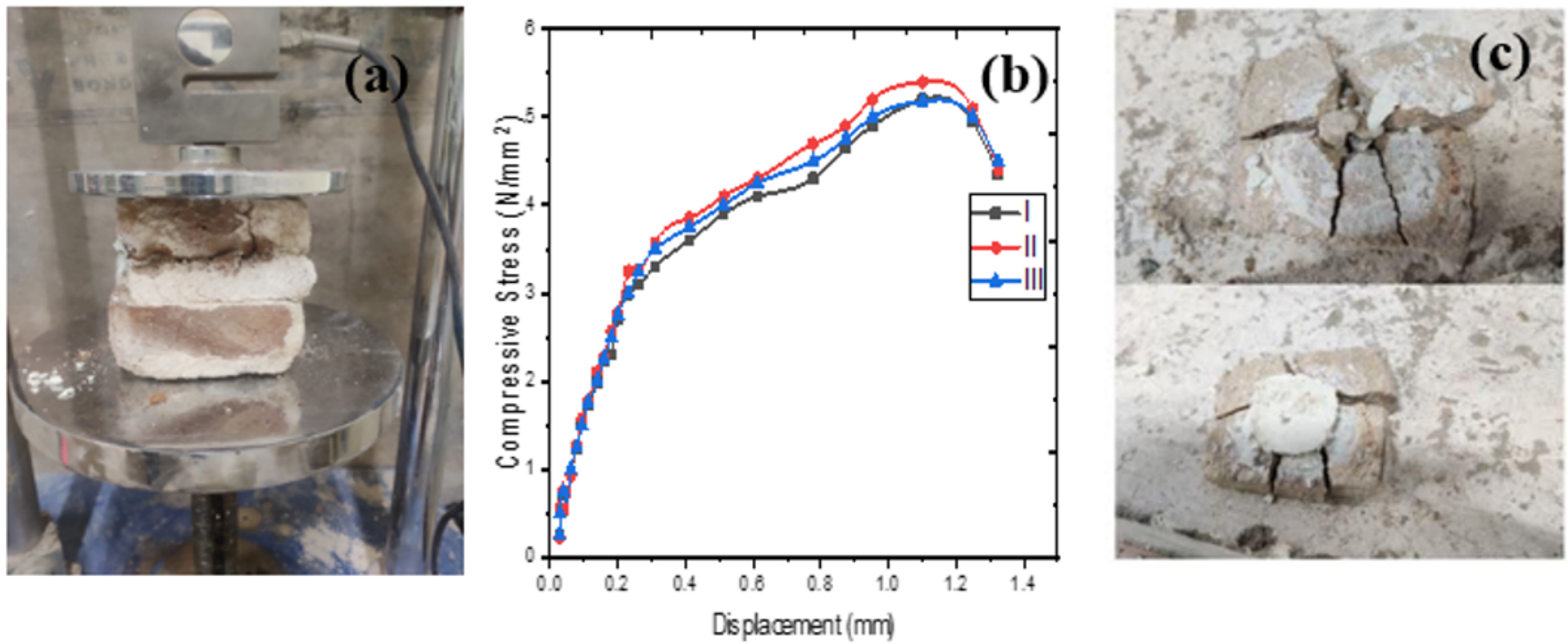

Figure 4

(a) Small scale masonry test, (b) Stress- displacement curve, (c)Crack of specimens after Double punch test 

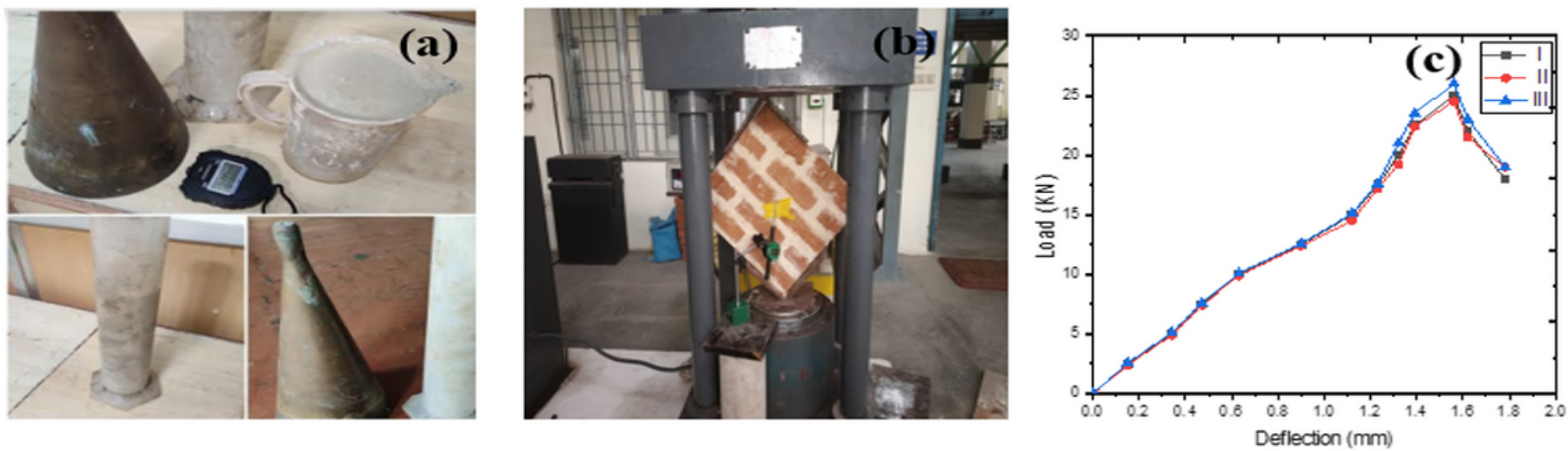

Figure 5

(a) Stability test, (b) Diagonal shear test (c)Load Vs deflection curve
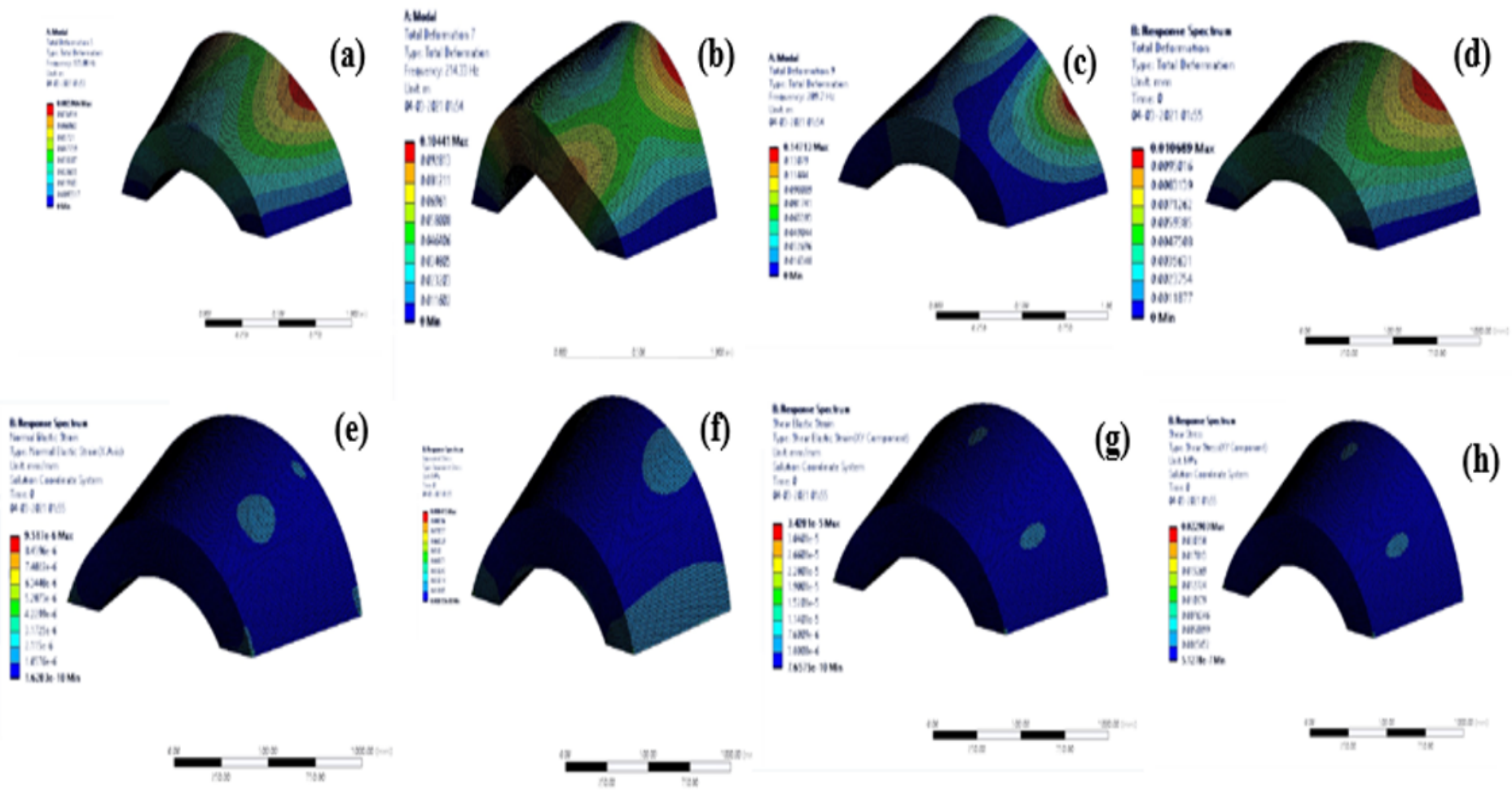

Figure 6

Response spectrum analysis of conical arch (a) Mode $5(135.88 \mathrm{~Hz})$, (b) Mode 7 (214.33 Hz), (c) Mode 9 (289.7Hz), (d)Total deformation, (e) Normal elastic strain, (f) Equivalent stress, (g) Shear Elastic strain, (h) Shear stress 

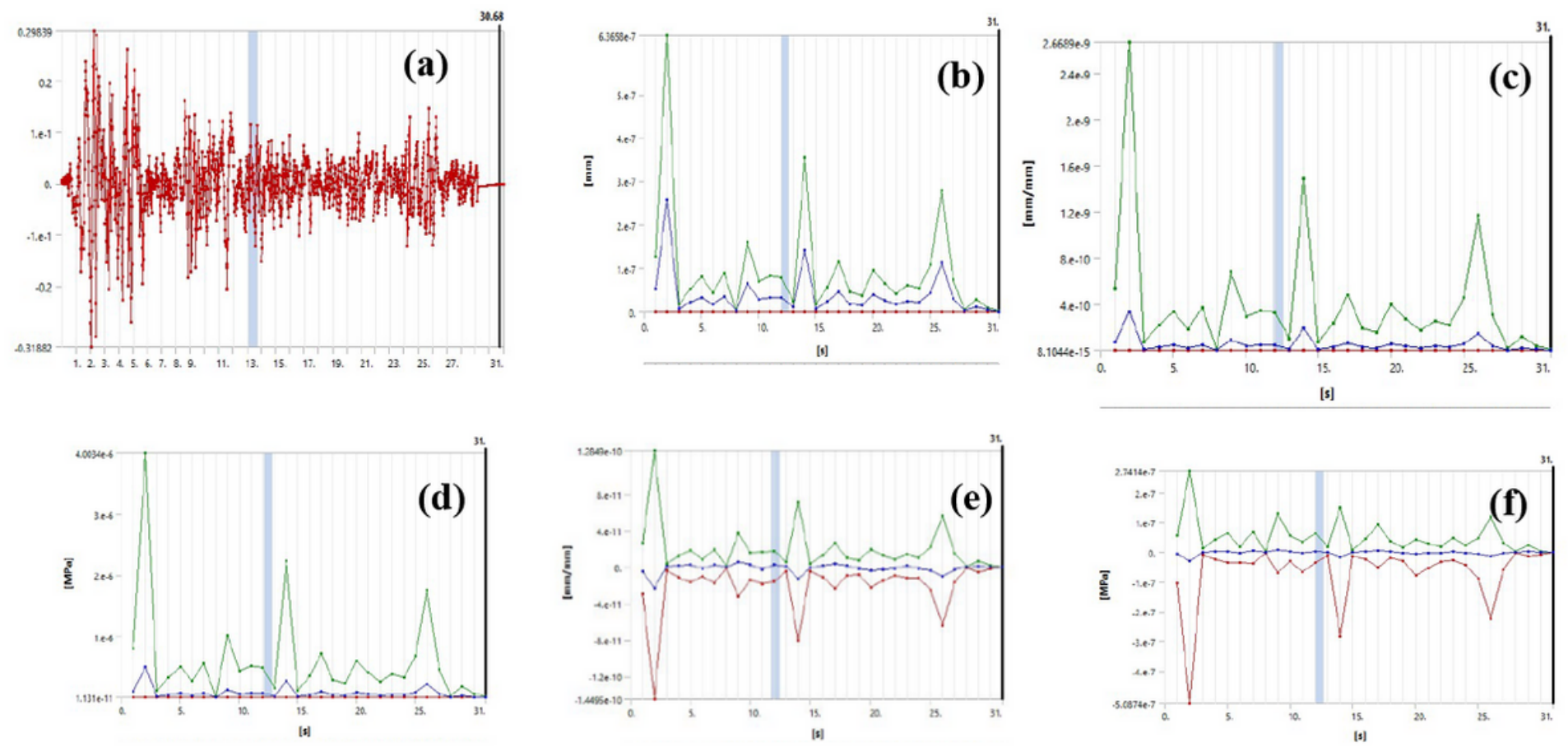

Figure 7

Time history analysis of conical arch (a) Time Vs Acceleration , (b)Time Vs Deformation , (c)Time Vs Equivalent Elastic Strain, (d)Time Vs Equivalent stress, (e)Time Vs Normal Elastic Strain, (f)Time Vs Normal stress.

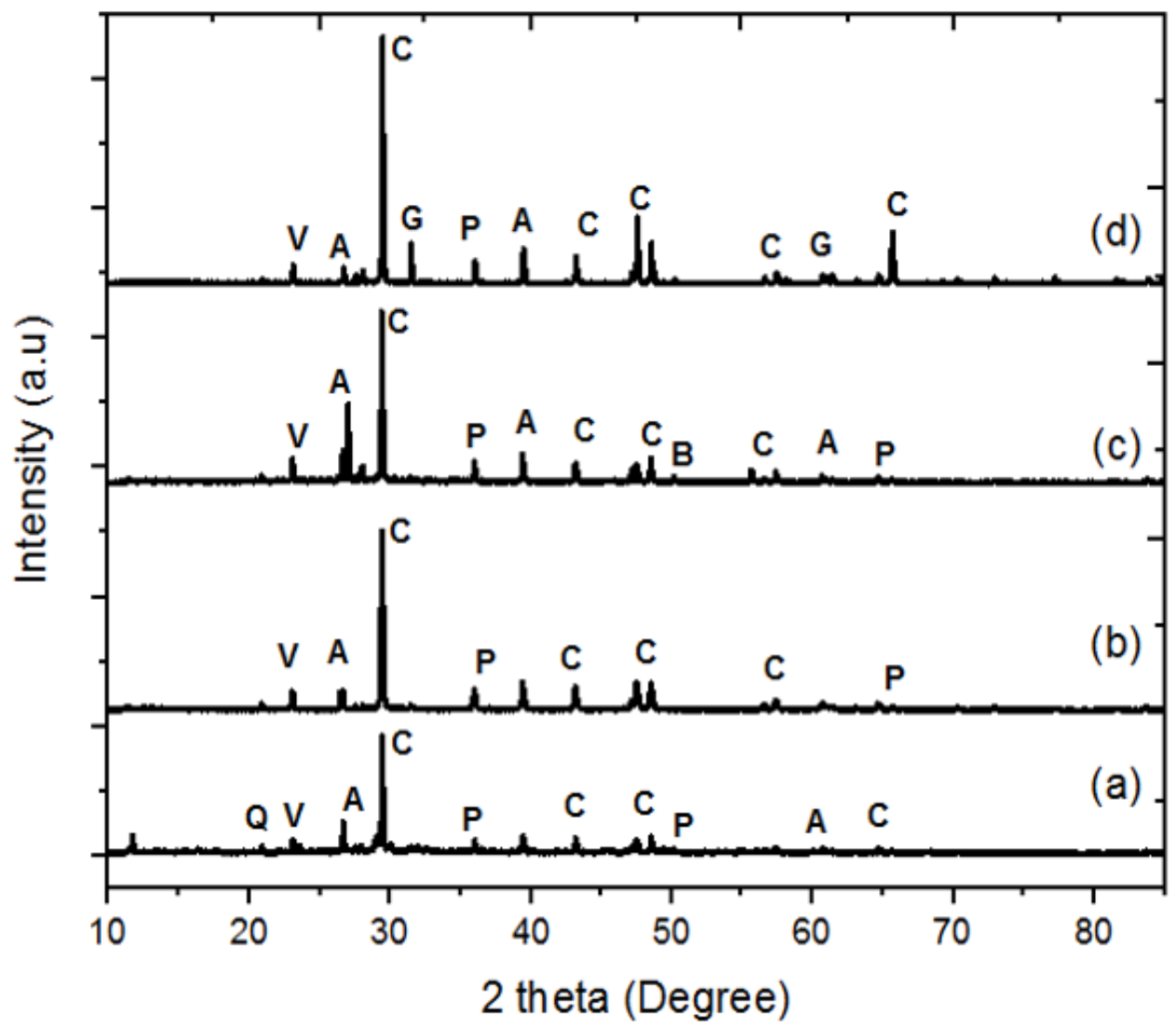

Q -Quartz, V- Vaterite, A- Aragonite, P-Portlandite, G-Gypsum, B-Brucite 


\section{Figure 8}

XRD Pattern of (a) F-1 (b) F-2 (c) F-3 (d) F-4
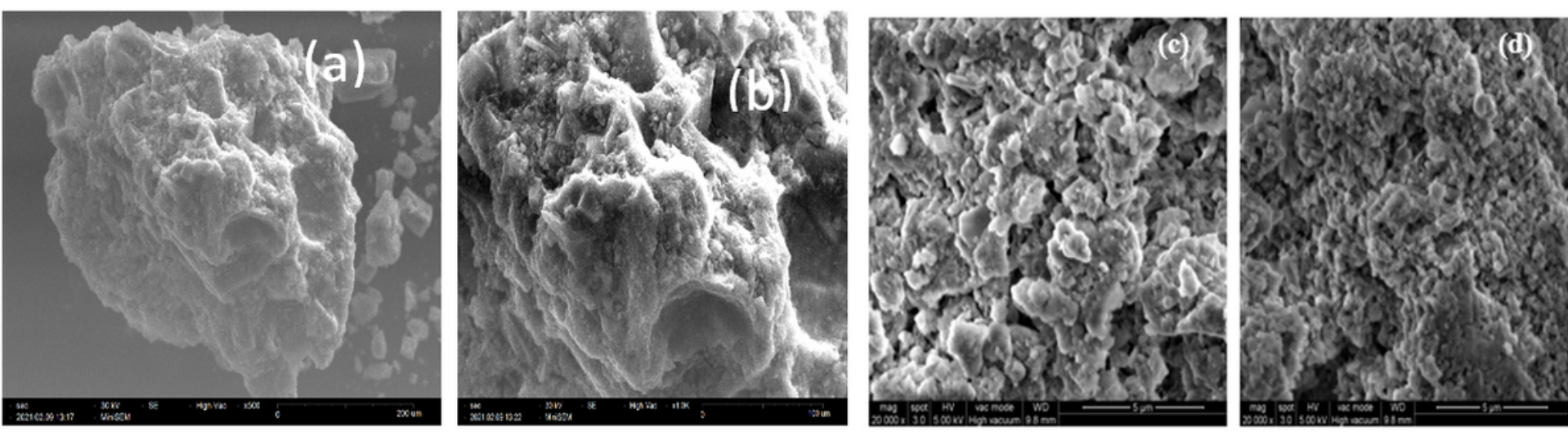

\section{Figure 9}

SEM analysis (a) F-1 (b) F-2 (c) F-3 (d) F-4 

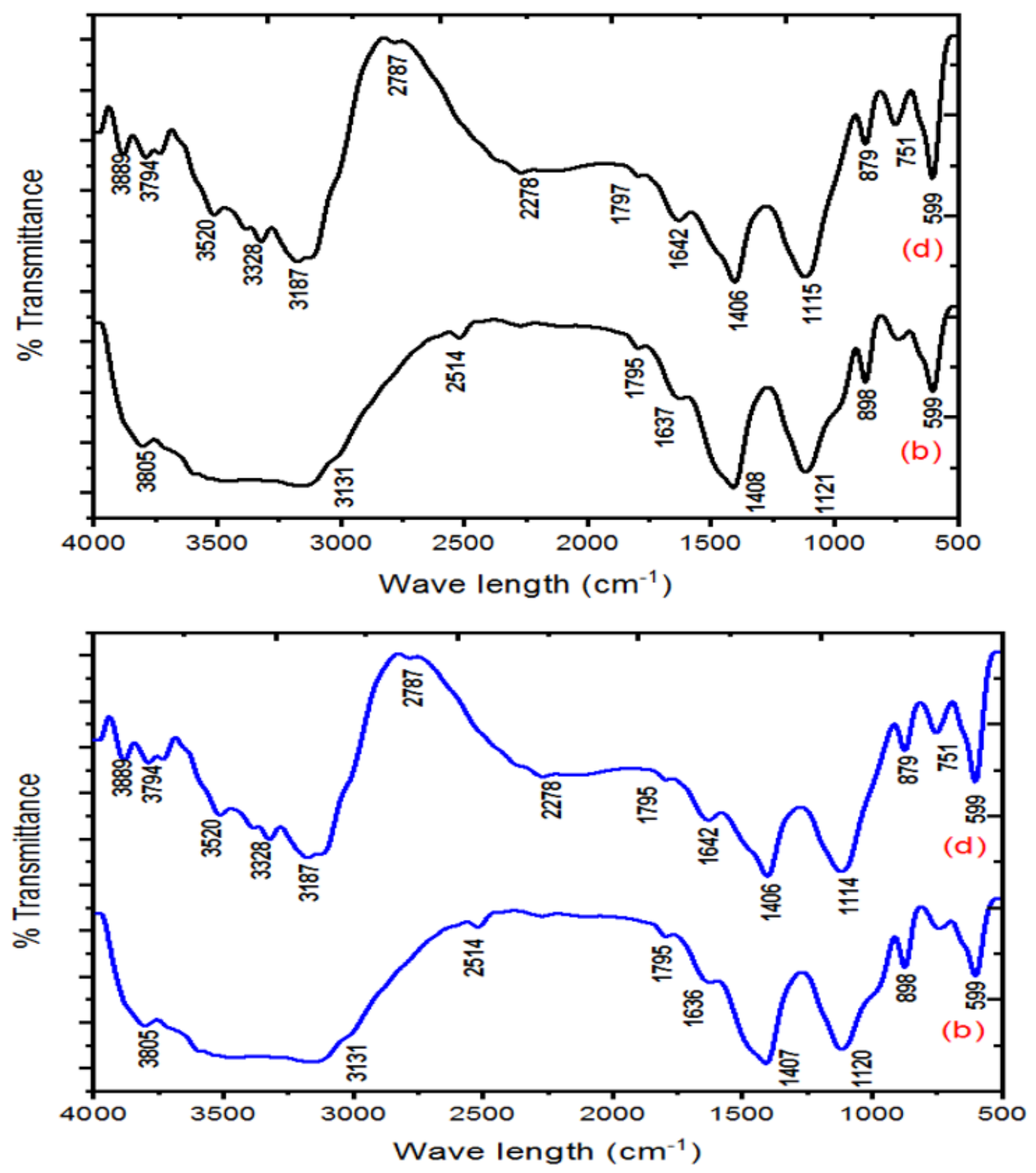

Figure 10

FTIR Graph for Sample (a) F-1 (c) F-3 (Plastering mortar) and (b)F-2 (d) F-4 (Bedding Mortar) 

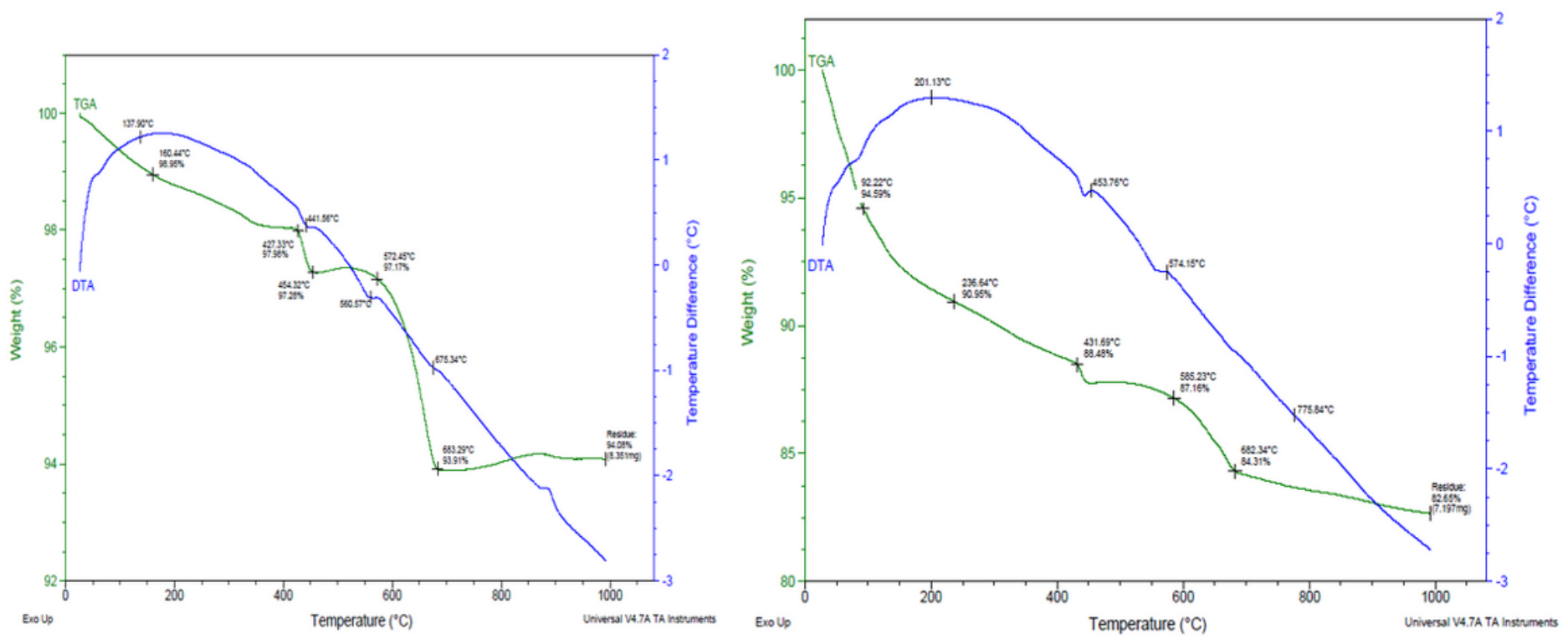

Figure 11

TGA and DTA of (a) F-1 (b) F-2
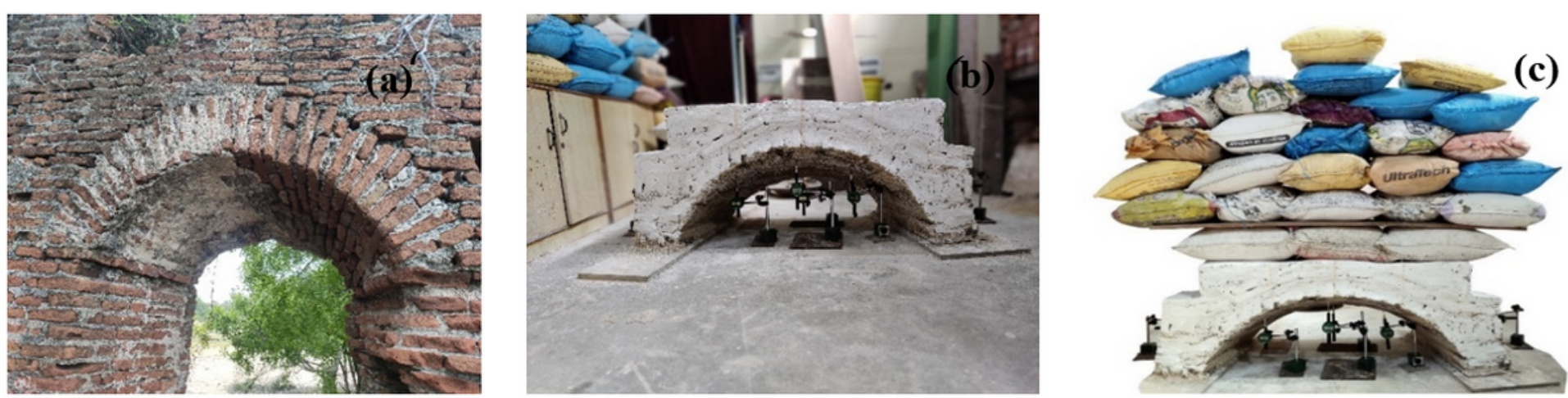

Figure 12

Arch from the fort (a) Existing Conical valley arch (b) Simulated Conical valley Arch (c) Plate load test on arch 


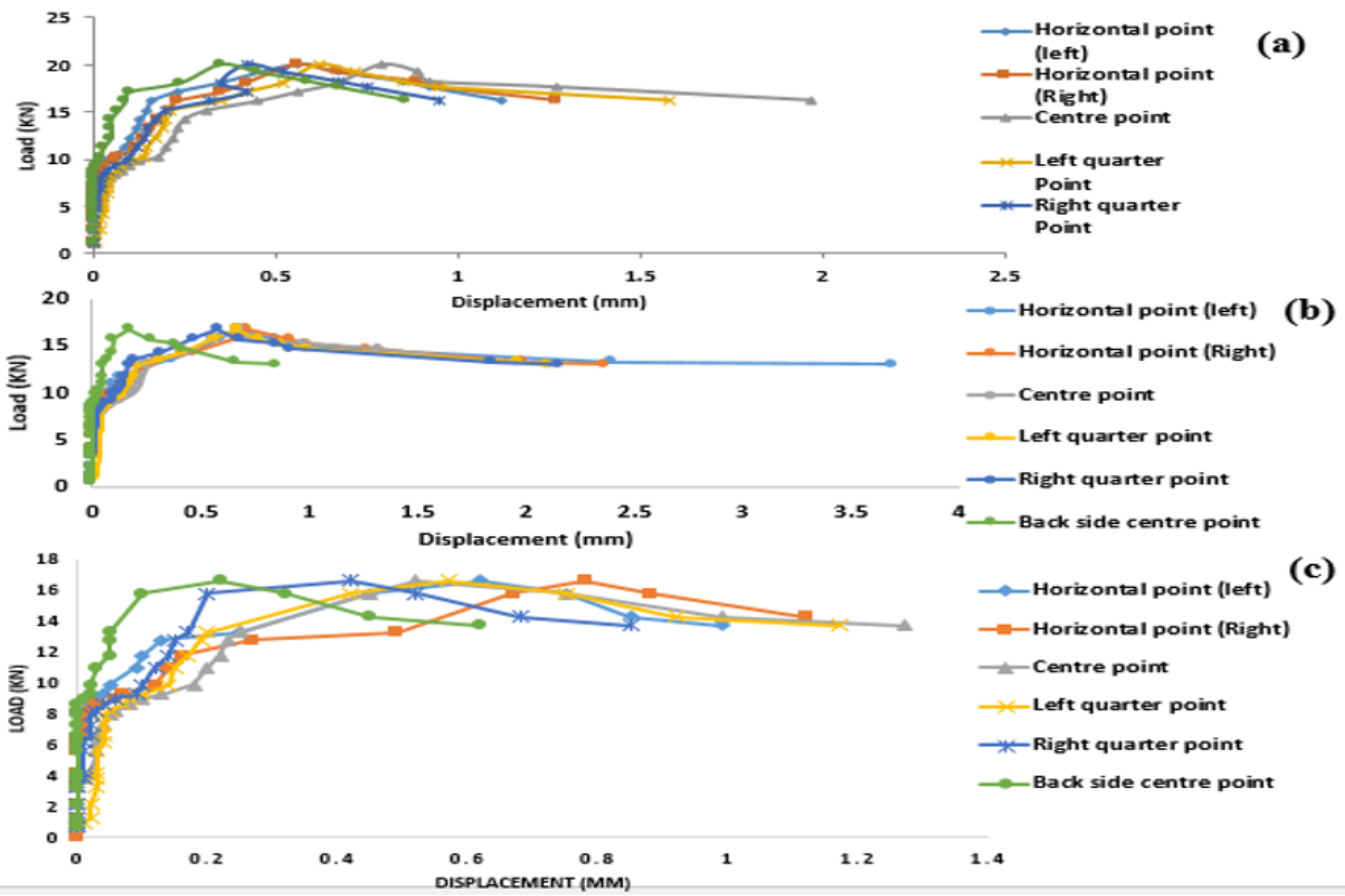

Figure 13

Sand bag-load test results on arch I,II,III.
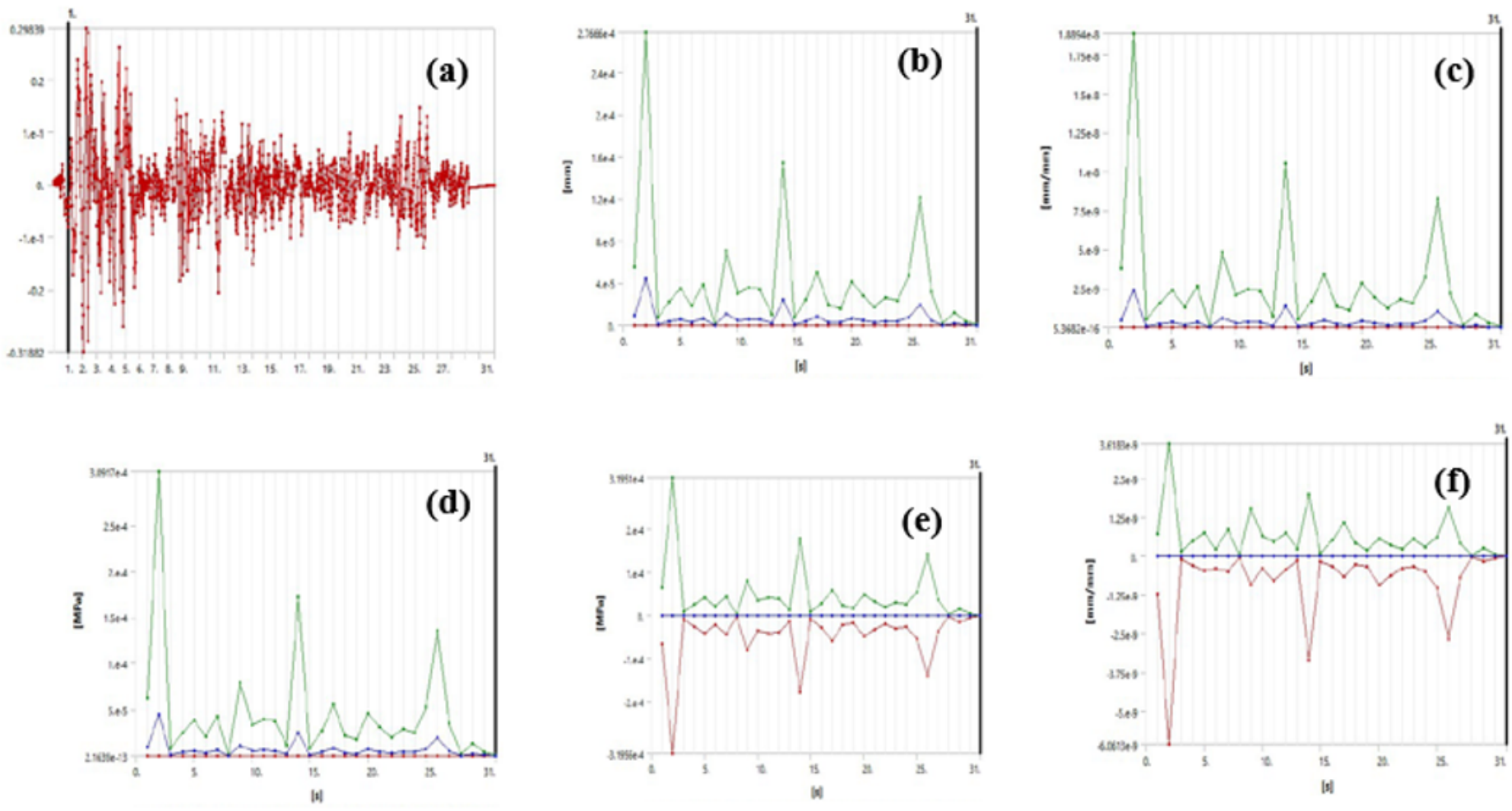
Figure 14

Response spectrum analysis of fort (a) Mode 2 (1.65 Hz),(b) Mode 7 (3.87 Hz) ,(c) Mode 10 (4.96 Hz),(d) Total deformation, (e) Normal elastic strain, (f) Equivalent stress, (g) Shear Elastic strain, (h) Shear stress 